
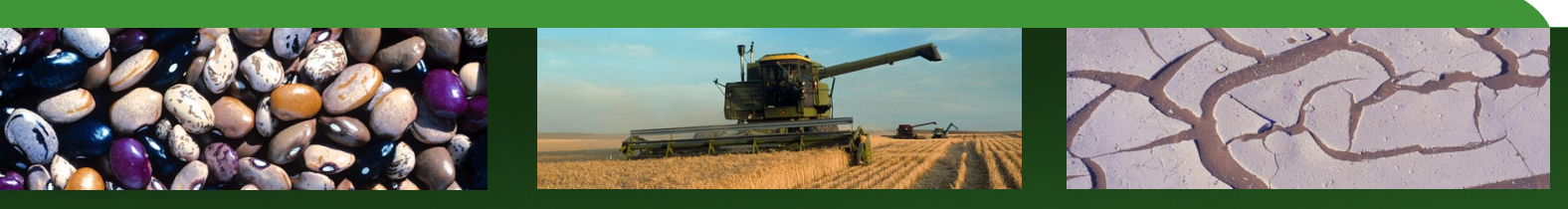

\title{
Post-2013 EU Common Agricultural Policy, Trade and Development
}

A Review of Legislative Proposals

By Alan Matthews

Professor Emeritus of European Agricultural Policy, Trinity College Dublin

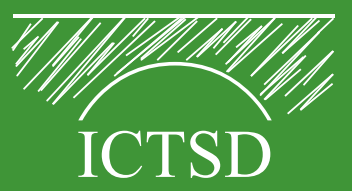




\section{Post-2013 EU Common Agricultural Policy, Trade and Development}

\section{A Review of Legislative Proposals}

\section{By Alan Matthews}

Professor Emeritus of European Agricultural Policy, Trinity College Dublin

\section{ICTSD}


A. Matthews - Post-2013 EU Common Agricultural Policy, Trade and Development: A Review of Legislative Proposals

\section{Published by}

International Centre for Trade and Sustainable Development (ICTSD)

International Environment House 2

7 Chemin de Balexert, 1219 Geneva, Switzerland

Tel: +41229178492

Fax: +41229178093

E-mail: ictsd@ictsd.org

Internet: www.ictsd.org

Chief Executive:

Ricardo Meléndez-Ortiz

Programmes Director:

Christophe Bellmann

Programme Team:

Jonathan Hepburn, Ammad Bahalim,

Malena Sell and Anne-Claire Adet

\section{Acknowledgments}

This paper has been produced under the ICTSD Programme on Agricultural Trade and Sustainable Development. ICTSD wishes gratefully to acknowledge the support of its core and thematic donors, including: the UK Department for International Development (DFID), the Swedish International Development Cooperation Agency (SIDA); the Netherlands Directorate-General of Development Cooperation (DGIS); the Ministry of Foreign Affairs of Denmark, Danida; the Ministry for Foreign Affairs of Finland; the Ministry of Foreign Affairs of Norway; Australia's AusAID; the Inter American Development Bank (IADB); and Oxfam Novib.

Christophe Bellmann, Alexander Gocht, Jonathan Hepburn, Hans Grinsted Jensen, Trees Robijns and Stefan Tangermann provided helpful comments on earlier drafts of this paper. This paper draws on research that Prof. Matthews undertook for the German Marshall Fund of the United States on Europe's Common Agricultural Policy and Developing Countries. The author is grateful to the German Marshall Fund for its support, and wishes to clarify that any opinions expressed in the paper are entirely his own.

For more information about ICTSD's Programme on Agricultural Trade and Sustainable Development, visit our website at http://ictsd.net/programmes/agriculture/

ICTSD welcomes feedback and comments on this document. These can be forwarded to Jonathan Hepburn at jhepburn [at] ictsd.ch

Citation: Mathews, Alan; (2011); "Post-2013 EU Common Agricultural Policy, Trade and Development: A Review of Legislative Proposals"; ICTSD Programme on Agricultural Trade and Sustainable Development; Issue Paper No.39; International Centre for Trade and Sustainable Development, Geneva, Switzerland, www.ictsd.org.

Copyright ICTSD, 2011. Readers are encouraged to quote and reproduce this material for educational, non-profit purposes, provided the source is acknowledged.

This work is licensed under the Creative Commons Attribution-Noncommercial-No-Derivative Works 3.0 License. To view a copy of this license, visit http: //creativecommons.org/licenses/bync-nd/3.0/ or send a letter to Creative Commons, 171 Second Street, Suite 300, San Francisco, California, 94105, USA.

The views expressed in this publication are those of the author(s) and do not necessarily reflect the views of ICTSD or the funding institutions.

ISSN $1817356 \mathrm{X}$ 


\section{TABLE OF CONTENTS}

ABBREVIATIONS, ACRONYMS AND GLOSSARY OF CAP TERMS iv

LIST OF TABLES AND FIGURES V v

FOREWORD vi

EXECUTIVE SUMMARY Viii

1. STATE OF PLAY OF THE CAP 2020 DEBATE 1

2. COMMISSION PROPOSALS 4

2.1 Direct Payments 4

2.2 Market Measures 9

$\begin{array}{lll}2.3 & \text { Rural Development } & 11\end{array}$

3. PRODUCTION AND TRADE EFFECTS OF THE LEGISLATIVE PROPOSALS 14

3.1 Impacts from Elimination of Milk and Sugar Quotas 14

$\begin{array}{lll}3.2 & \text { Greening Impacts } & 17\end{array}$

3.3 Impact of Moving to More Uniform Direct Payments 17

$\begin{array}{lll}3.4 & \text { Coupling Impacts } & 18\end{array}$

3.5 Future WTO Compliance of EU Direct Payments 20

4. FINAL REFLECTIONS 23

4.1 Food security impacts of the Commission proposals 23

4.2 Coupled payments 24

4.3 Sugar 24

4.4 Cotton 25

4.5 Rice 25

4.6 Final remarks 25

$\begin{array}{lr}\text { ENDNOTES } & 27\end{array}$

$\begin{array}{ll}\text { REFERENCES } & 30\end{array}$

$\begin{array}{ll}\text { ANNEX } & 33\end{array}$ 


\section{ABBREVIATIONS, ACRONYMS AND GLOSSARY OF CAP TERMS}

ACP
AMS
CAP
CMO
CSF
MFF
PEA
SAPS
SMR
SPS
WTO
Cross-compliance

Entitlement

LEADER

Modulation

Naked hectares

Natura 2000

Pillar 1 and Pillar 2
African, Caribbean and Pacific

Aggregate Measure of Support

Common Agricultural Policy

Common Market Organisation

Common Strategic Framework

Multi-annual Financial Framework

Potentially Eligible Area

Single Area Payment Scheme

Statutory Management Requirements

Single Payment Scheme

World Trade Organisation

Cross-compliance links direct payments to farmers to their respect of environmental and other requirements set at EU and national levels.

Entitlements are a right to receive payments under the SPS scheme. Entitlements were given to farmers actively farming at the date each Member State introduced the scheme. Payments are granted where farmers have eligible hectares at their disposal to activate the appropriate number of entitlements. In the 2007-2013 period, entitlements could be transferred or sold under specified conditions.

LEADER stands for Liaison entre actions de développement rural (Links between actions of rural development). It is a method of mobilising and delivering rural development in local rural communities through local action groups.

Modulation provides a means to ensure the transfer of CAP funds from direct aids to farmers and market measures ('Pillar 1' of the CAP) to rural development measures ('Pillar 2').

Utilised agricultural area on which an entitlement is not being claimed, but which could be used to activate an entitlement.

Natura 2000 is an EU-wide network of nature protection areas established under the 1992 Habitats Directive and is the centrepiece of EU nature \& biodiversity policy. The aim of the network is to assure the long-term survival of Europe's most valuable and threatened species and habitats.

The separation of the CAP into two Pillars is because they are funded through different budget envelopes with different rules. Pillar 1 finances mainly market measures and annual payments to farmers and is funded by the European Agricultural Guarantee Fund. Pillar 2 is based on multiannual programming and member states co-finance the programmes, and is financed by the European Fund for Rural Development. 


\section{LIST OF TABLES AND FIGURES}

Table 1. Summary of Commission proposals for CAP reform

Table 2. Measures proposed in the rural development regulation

Figure 1. Redistribution of EU direct payments under the MFF formula in 2020

Figure 2. Quota utilisation for cow's milk delivered to dairies, quota years ('000t) 
A. Matthews - Post-2013 EU Common Agricultural Policy, Trade and Development: A Review of Legislative Proposals

\section{FOREWORD}

Soon - too soon for comfort - after the 2008 shock situation of rapidly worsening agricultural shortages, world markets are once again displaying persistent high grain prices and are plagued by uncertainty. The world's geographical distribution of agricultural production is highly heterogeneous, as is food consumption, and to a great extent this is the result of policies rather than comparative or agro-ecological advantages. Imbalances in production and consumption have much to do with the effect of large managed food systems, such as the European food system, on the rest of the world. What may have once been a regional food economy is comprehensively and increasingly global in scope and has demonstrated implications for food security, development prospects and trade policies.

Cooperation in agriculture is a major feature of the European Union, and of its uniquely successful common market. Since 1990 the farm sector's cooperative scheme - the Common Agricultural Policy (CAP), through which common resources are collectively allocated - has undergone a series of reforms to adapt to the dynamism of political, economic and social realities. Since 1992, reforms have been progressively pro-market, moving away from the dirigisme that characterized the CAP in its early years. The trend seems to be towards avoiding, as much as possible, distortions to prices and production decisions, and instead placing more attention on local rural development and environmental dimensions of the countryside. Policy-makers, business groups and civil society organisations are at this time in the midst of a discussion over the future of the CAP for the 20132020 budget cycle.

The European Commission has now finalised leglislative proposals that set out the overall direction of CAP reform in the post-2013 period. While these are subject to further debate amongst EU member states and in the European Parliament, the proposals already provide a fairly advanced picture of how reform of the CAP may proceed. The analysis that follows is based on a thorough review of these proposals.

Reform this time around is particularly challenging, for reasons that go beyond the implications for the non-European economy and the unfinished Doha talks at the WTO on agricultural reform. This is so, given the inclusion now of traditional competitive large agricultural producers such as Poland and Hungary in the European space, and the imperative for a more equitable distribution of support and benefits, and for a rationalization of land, water and energy use in agriculture. The European public's demand is particularly firm now for safeguarding of ecosystem services, sustainable farming and locally-developed practices, and smallholder agriculture and rural livelihoods. In many ways, the resulting post-2013 CAP raises more complex expectations, from within and outside Europe, than any regional farm policy before.

While direct transfers, mostly in the form of subsidies, are likely to continue being granted primarily through payments designed and meant as 'decoupled' from production, the scale of support to be provided is likely to determine a competitive advantage to European farmers in relation to their counterparts in other parts of the world. Also important is the choice of instruments used to deliver support, and the impact on production resulting from the 'greening' requirements being proposed by the Commission.

This paper aims to provide policy-makers, negotiators and other stakeholders with an objective, evidence-based assessment of the most important ways in which the proposed reforms of the EU's Common Agricultural Policy (CAP) could affect trade flows, looking in particular at the impact on developing countries. Countries are heterogeneous in their vulnerability to changes in world prices resulting from schemes such as the CAP. Paraphrasing the author, we now know better than ever 
how the effects on countries depend on the commodity composition of their trade - whether they are net importers or exporters of goods protected by the CAP, and whether they have preferential access to the EU market and thus are able to share in some of the benefits of CAP protection. We intend to revert to more analysis once the reform package is final, and hope at this time that this paper provides the guidelines for individual countries to undertake their own studies.

I trust that the reader will find this work by Professor Alan Mathews a timely contribution to this debate, and that it allow the many concerned stakeholders to interact with their policymakers in ensuring a sustainable development supportive outcome, both for Europe and the rest of the world.

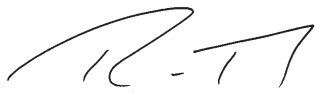

Ricardo Meléndez-Ortiz

Chief Executive, ICTSD 
A. Matthews - Post-2013 EU Common Agricultural Policy, Trade and Development: A Review of Legislative Proposals

\section{EXECUTIVE SUMMARY}

The European Commission forwarded legislative proposals for reform of the Common Agricultural Policy (CAP) to the European Council and the European Parliament in October 2011. These proposals, which build on an earlier Communication of the Commission in November 2010, initiate the legislative procedure to agree the new regulations which may take up to 18 months to complete. Because of the scale of the EU as a major player in global agricultural markets, changes to its agricultural policy can potentially have repercussions for other countries. This paper analyses what the trade and development implications of the Commission's proposals might be.

The Commission proposes changes to the EU's system of direct payments to farmers, market management and rural development policies. In addition, parallel negotiations are taking place on the Commission's legislative proposal for a new medium-term financial framework for the EU budget for the period 2014-2020. The outcome of these negotiations will determine the overall budget available for the EU's agricultural policy over this period.

The Commission proposes to end the existing direct payment systems in both old and new member states. These will be replaced by a uniform but more differentiated system. The direct payments budget will be redistributed between member states to ensure greater equality in payment levels across countries. A basic payment will be maintained for all EU farmers as a form of direct income support. This will be topped up with further payments to encourage practices which address environment and climate policy goals, to assist farmers in areas with specific natural constraints, and to help new entrants. The basic payment will be capped (albeit at a high level). Voluntary coupled payments can be continued where they can be shown to be necessary to maintain current levels of production.

The EU has reformed most of its market management instruments for different commodities in the past decade. The new proposals make minor adjustments. Supply controls on milk, sugar and the planting of vines will be eliminated. The possibility to use crisis interventions in the event of market disturbances is generalised across commodities. Measures to strengthen the bargaining power of producers in the food chain will be introduced.

Rural development policy will be made more flexible for member states, and will be better coordinated with the territorial interventions of other EU funds. An optional co-financed risk management tookit is made available for member states to use. New institutional mechanisms for innovation are proposed, backed up with a larger budget for agricultural and food research, to help improve the competitiveness of EU agriculture and to address environmental and climate policy challenges.

Developing countries are increasingly heterogeneous in the way they are affected by changes in world food prices and, thus, by these changes in EU agricultural policy. The effects depend on the commodity composition of their trade, whether they are net importers or exporters of commodities protected by the CAP, and whether they have preferential access to the EU market and thus are able to share in some of the benefits of CAP protection. Each country must individually undertake its own analysis to assess how it might be affected. It is hoped that the analysis in this paper provides some relevant guidelines and parameters for such country-specific analyses.

With the possible exceptions of sugar and rice, the order of magnitude of the effects to be expected from implementation of the Commission's legislative proposals for CAP reform post-2013 will be minor, particularly in the context of the swings in world market prices experienced since 2008. The paper concludes that the greater emphasis on encouraging farmers to adopt environmentally- 
friendly farming practices, and the redistribution of direct payments towards farms in more marginal and less productive areas, will lower the EU's production potential compared to a status quo scenario. This will affect arable production in particular. Resulting higher feed prices will reduce EU pig and poultry production and will also constrain any expansion in milk production which might be anticipated after the elimination of milk quotas. The slight reduction in coupled cotton payments will lead to lower EU cotton production.

While the abolition of milk quotas is not expected to have any significant impact on world markets, the proposed elimination of sugar quotas could result in a substantial increase in production, depending on the level of world market prices over the next decade. This would result in lower imports from preferential suppliers, particularly least developed countries and ACP exporters. However, there are divergent views on the potential for expanded EU sugar production and thus considerable uncertainty regarding the future of EU sugar imports. Moreover, the continuation of coupled supports which, on the basis of past experience, will be directed mainly to beef and sheep production, together with the effect of redistributing direct payments to more marginal farming areas where beef and sheep production is more important, will keep EU production of these commodities higher than would otherwise be the case.

This CAP reform was not intended to address the trade barriers used to keep some EU market prices higher than world market levels. The EU has reduced the impact of these barriers for a number of developing countries through extending the scope of preferential access under various trade agreements, and a further reduction is being negotiated in the WTO Doha Round. Nonetheless, developing countries will be disappointed that the opportunity was not taken in this reform to set a final date for the ending of export subsidies. A more ambitious CAP reform, in which the targeting of direct payments was pursued more insistently and coupled payments were phased out, would also have a greater impact in removing the remaining distortions caused by the CAP to world markets. 
A. Matthews - Post-2013 EU Common Agricultural Policy, Trade and Development: A Review of Legislative Proposals

\section{STATE OF PLAY OF THE CAP 2020 DEBATE}

The debate on reform of the EU's Common Agricultural Policy (CAP) enters a new phase in October 2011 with the publication of the Commission's legislative proposals for the new CAP regulations after 2013. The proposals take the form of four main legal instruments which will replace the existing regulations governing the CAP, as follows:

- A regulation governing direct payments;

- A regulation governing rural development payments;

- A regulation revising the single Common Market Organisation regulation (CMO);

- A horizontal regulation covering financing, management and monitoring of the CAP.

The publication of the Commission proposals initiates the procedure to create the legislation which will underpin the CAP after 2013 (see Box 1). These legislative proposals follow from the Communication of the Commission on the CAP towards 2020 published in November 2010 which set out a number of options for future CAP reform (European Commission, 2010a). A previous ICTSD paper discussed the background to the Commission's initiative and presented a preliminary analysis of its proposals and their likely implications for third countries (Matthews, 2010; see also European Parliament, 2010a).

This paper takes the story forward one further year in which the Commission's November 2010 Communication has been widely debated. The Commission issued a consultation document for the impact assessment in January 2011 (European Commission, 2011a) which further elaborated on its thinking behind the three scenarios for reform (called the adjustment, integration and refocus scenarios) set out in the Communication. ${ }^{1}$ A total of 517 responses were received, mainly from producer organisations, during the consultation period. The European Parliament debated the Communication on the basis of a report prepared by the rapporteur from its Committee on Agriculture and Rural Development, Albert Deß (European Parliament, 2011a). The Committee's report received a total of 1267 amendments before an agreed resolution was passed by the Parliament on 26 June 2011 (European Parliament, 2011b).

Another important step was the publication by the Commission in June 2011 of its proposal for the next medium-term financial framework (MFF) covering the period 2014-2020 (European Commission, 2011b). This gave the first indication of the resources likely to be available for agricultural policy during this period. The MFF proposed a small decrease in real terms but a small increase in nominal terms in the CAP budget for the period 2014-2020. ${ }^{2}$ As the Commission proposal envisages that the overall EU budget (in commitment appropriations) would increase only slightly in real terms, this implies that the share of the CAP in the EU budget would fall from 39\% in 2013 to $33 \%$ in $2020 .^{3}$ Maintaining the agricultural budget in nominal terms was seen as an unexpected victory for agricultural interests given the many competing demands being made on the EU's limited resources in the light of the Europe 2020 strategy and external challenges and the need for budget austerity at all levels of government. ${ }^{4}$ It was a vindication of the strategy of the Agriculture Commissioner Dacian Cioloș who had attempted to reposition the CAP as a greener and more targeted policy more aligned with the Europe 2020 goals of "smart, sustainable and inclusive growth". However, the MFF becomes a legally binding act only after a special legislative procedure requiring its adoption by unanimity by the Council, after obtaining the consent of the Parliament by a majority of its members. This process should be completed by the second half of 2012 to allow enough time for the legal bases for the different programmes and projects funded by the budget to be agreed before they commence on 1 January 2014. 


\section{Box 1. The EU's Ordinary Legislative Procedure}

The Commission proposals for new CAP regulations are only the first step in the legislative procedure. The proposal now enters the co-decision process between the Council of Ministers and the European Parliament. In the first reading, the Parliament will adopt its position by a simple majority and the Council will adopt its position by a qualified majority. If the Council adopts the Parliament's position, then the regulations are adopted.

It is more likely that the positions taken by the two parties will differ, in which case the process moves to a second reading in both the Parliament and the Council. Within a three month period, the Parliament can either approve the Council's common position (in which case the regulations are adopted) or propose amendments to the Council's position which are then put to the Council and the Commission for their opinion. The Council then has a further three months in which to accept the Parliament's amendments by qualified majority (or by unanimity where the Commission has given a negative opinion). If the Parliament's amendments are approved, then the regulations become law. Otherwise, a Conciliation Committee is convened within a six week period.

The Conciliation Committee consists of an equal number of Council and Parliament representatives, assisted by the Commission. It has available to it the Commission proposal, the Council's common position, the amendments proposed by the Parliament and the Commission's opinion on these. The Committee has six weeks to draft a joint text which must be approved by a qualified majority of the members of the Council or their representatives and by a majority of the members representing the European Parliament. If a joint text cannot be agreed, then the procedure stops. If a joint text is agreed, then it goes to the Council and Parliament for approval. The Council and Parliament then have a further six weeks to approve the joint text, with the Council acting by a qualified majority and Parliament by a majority of the votes cast.

It is expected that the final decisions will be taken under the Irish Presidency of the Council in the first half of 2013.

Source: European Parliament (2010b). The detailed procedures are set out in Joint Declaration (2007).

The current two pillar structure of the CAP is maintained "with annual mandatory measures of general application in Pillar 1 complemented by voluntary measures better tailored to national and regional specificities under a multi-annual programming approach in Pillar 2" (European Commission, 2011f). Separate regulations deal with Pillar 1 (direct payments) and Pillar 2 (rural development). The third regulation on the single common market organisation deals with market measures and the scope for public intervention in EU commodity markets and the functioning of the food chain. Finally, the horizontal regulation corresponds to the current financing regulation but expanded to bring together various common provisions.

This paper evaluates the trade and development implications of these proposals, specifically to draw out their implications for developing countries. The main elements in the Commission proposals are summarised in Table 1 and described in Section 2. The likely trade and development effects of the proposals and their effect on the EU's compliance with its WTO commitments under the Uruguay Round Agreement on Agriculture and potentially under a future Doha Round Agreement are analysed in Section 3. Section 4 reflects on the potential implications for developing countries. 
A. Matthews - Post-2013 EU Common Agricultural Policy, Trade and Development: A Review of Legislative Proposals

Table 1. Summary of Commission proposals for CAP reform

\begin{tabular}{|c|c|c|}
\hline Direct Payments & Market Measures & Rural Development \\
\hline $\begin{array}{l}\text { Convergence of direct } \\
\text { payments across member } \\
\text { states } \\
\text { New basic payment to replace } \\
\text { the Single Payment Scheme } \\
\text { and the Single Area Payment } \\
\text { Scheme } \\
\text { New "green" component of } \\
\text { direct payments } \\
\text { Greater targeting of } \\
\text { beneficiaries } \\
\text { New rules for coupled } \\
\text { payments } \\
\text { Changed cross-compliance } \\
\text { rules }\end{array}$ & $\begin{array}{l}\text { Confirmation of the ending of } \\
\text { milk quotas, of sugar quotas } \\
\text { (with one year delay), and of } \\
\text { vine planting ban } \\
\text { Extension of the market } \\
\text { disturbance clause to all } \\
\text { commodities under the CMO } \\
\text { Measures to improve } \\
\text { functioning of the food chain } \\
\text { Measures to support quality } \\
\text { production }\end{array}$ & $\begin{array}{l}\text { New rural development } \\
\text { priorities to replace current } \\
\text { axes } \\
\text { Better coordination with other } \\
\text { EU funds } \\
\text { New criteria to allocate Pillar } 2 \\
\text { funds across member states } \\
\text { Simplification of supported } \\
\text { measures } \\
\text { Enhanced risk management } \\
\text { toolkit } \\
\text { European Innovation } \\
\text { Partnership } \\
\text { Proposals on monitoring and } \\
\text { evaluation }\end{array}$ \\
\hline
\end{tabular}

Source: Author's compilation. 


\section{COMMISSION PROPOSALS}

\subsection{Direct Payments}

The aspects of the Commission proposals which attracts most attention relate to the future design of direct payments. This is partly because the budget for direct payments is the most important element of EU agricultural policy, accounting for $72 \%$ of EU CAP expenditure in the 2012 budget, and partly because of their important role in underpinning farm income in the EU (Matthews, 2010). ${ }^{5}$

Currently, direct payments are provided to farmers under two different schemes, the Single Payment Scheme (SPS) in the old member states (plus Malta and Slovenia) and, as a temporary derogation to the SPS, the Single Area Payment Scheme (SAPS) in the new member states. The SPS can be implemented on the basis of a historical model or a regional model or a combination of both (so-called "hybrid" model). In the historical model, farmers were given payment entitlements based on their eligible hectares and payments received in a reference period (2000-2002). The regional model is based on a uniform value of payment entitlements within a region, while the hybrid model is a combination that can be either static or dynamic over time. Entitlements must be activated each year on the basis of an equivalent number of hectares of eligible agricultural land. Farmers in receipt of direct payments must abide by so-called cross-compliance, which includes observing statutory management requirements as well as maintaining land in good agricultural and environmental condition (but without any obligation to undertake production on this land). With successive reforms and progressive decoupling of support under different commodity regimes (cotton, olive oil, fruits and vegetables, etc.) since its introduction, the system of SPS entitlements has become increasingly complex over time.

The design of direct payments has been controversial for two other reasons. First, direct payments were originally introduced as part of the 1992 MacSharry reform to compensate for reductions in administrative prices which were implemented at that time, now 20 years in the past. They remain largely linked in the old member states to past levels of production on individual farms, particularly in those member states that opted for the historical model to establish entitlements to the decoupled payments introduced after 2005. For both reasons the justification for, and legitimacy of, direct payments has been questioned. One of the objectives of the Commission's proposal is to create a new legitimacy for direct payments through better targeting of payments both to public goods and to beneficiaries.

Second, the new member states have made clear they wish to see greater equality in the distribution of payments across member states, a demand which the Commission's November 2010 Communication recognised as legitimate. The direct payment expenditure ceilings negotiated in the accession treaties with the new member states resulted in much lower payments per hectare than in the old member states, something which the new member states insist should be changed.

The stated aim of the direct payments regulation is "to better target support to certain actions, areas and beneficiaries, as well as to pave the way for convergence of the level of support within and across member states" (European Commission, 2011f). The Commission's solution to these conflicting pressures is to abolish entitlements under the SPS and SAPS schemes and to replace these with entitlements under a new basic payment scheme from 2014 on, which will be based only on the regional model with a uniform level of payments inside each region. The basic payment will be complemented by a series of additional payments funded under the direct payments national ceiling made available to each member state. These include a mandatory green payment $30 \%$ of the annual national ceiling) to farmers 
A. Matthews - Post-2013 EU Common Agricultural Policy, Trade and Development: A Review of Legislative Proposals

following agricultural practices beneficial for the climate and the environment; a voluntary additional payment (up to $5 \%$ of the national ceiling) for farmers in disadvantaged areas; a mandatory additional payment to new entrants enrolled in the basic payment scheme (up to $2 \%$ of the national ceiling) and a simplified scheme for small farmers (up to $10 \%$ of the annual national ceiling). Provision is made for a voluntary coupled support scheme for specific types of farming or specific agricultural systems that experience difficulties and which are particularly important for economic and/ or social reasons (up to $5 \%$ of annual national ceiling with the possibility to go beyond this in particular cases). These various payments are now discussed in more detail.

\subsubsection{Convergence of payment values across member states}

The disparities between member states arising from the way in which the budget for direct payments has been allocated are indeed striking. Commission figures show that the average direct payment per hectare of potentially eligible area (PEA) for the year 2013 is $€ 94.7$ in Latvia and $€ 457.5$ in the Netherlands, whereas the EU-27 average is $€ 269.1$ (European Commission, 2011c). With a view to a more equitable distribution of support, the Commission proposes that the value of entitlements should converge at national level towards a more uniform value.

The Commission considered various options, some of which are set out in the impact assessment (European Commission, 2011c). Essentially, the choice came down to using some version of "objective criteria" to determine the allocation between member states, or to use a more pragmatic formula. The objective criteria considered included GDP per head, the amount of Agricultural Work Units (AWU) or gross value added in agriculture/AWU (for economic criteria) or the area in less favoured areas, Natura 2000 zones or area under permanent pasture (for environmental criteria). From the Commission's perspective, the difficulty with any of the formulae using objective criteria is that they would lead to a very substantial redistribution of the direct payments budget across member states. Under one version using objective criteria for redistribution, the amount redistributed could amount to $€ 4.5$ billion out of a direct payments budget of around $€ 42.8$ billion. The Commission commented that this "is likely to make it politically unacceptable for many member states to agree to such a redistribution" (European Commission, 2011c).

Thus the Commission's direct payments regulation opts for the pragmatic approach. It proposes a very limited redistribution initially of direct payment envelopes (funds) between the member states, following the formula in the Commission's proposal for the 2014-2020 medium-term financial framework (European Commission, 2011b). This envisages that, for countries currently receiving less than $90 \%$ of the EU average payment per eligible hectare, one-third of the gap between their current figure and $90 \%$ of the EU-27 average is closed. This limited effect is confirmed in the impact assessment, which calculates that the redistribution would amount to just $€ 738$ million out of a total budget of $€ 42.8$ billion. 
Figure 1. Redistribution of EU direct payments under the MFF formula in 2020

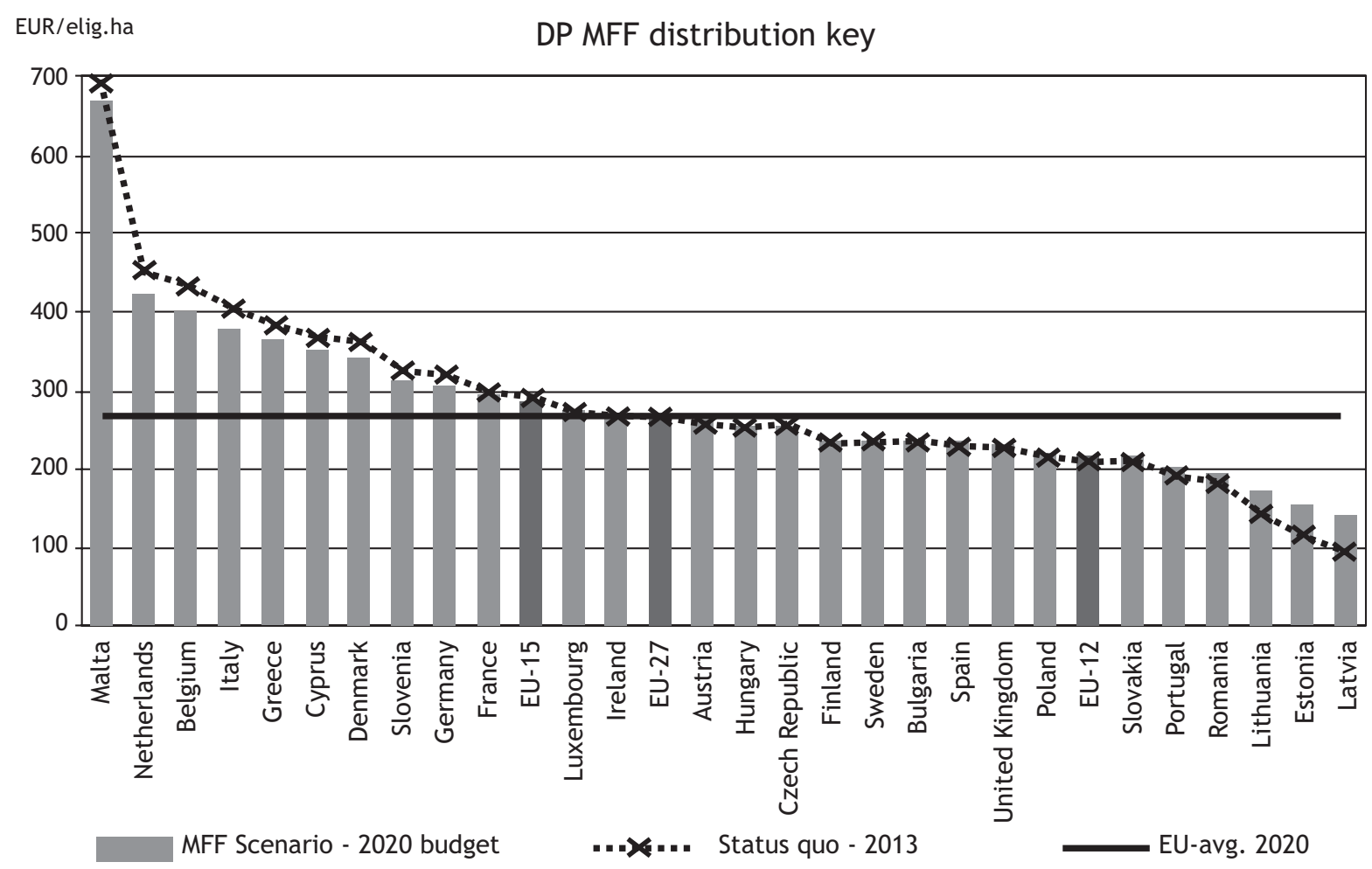

Source: European Commission, 2011c

The preamble to the proposed direct payments regulation also includes an aspirational commitment that the debate on the next Multiannual Financial Framework for the period starting in 2021 should focus on the objective of complete convergence through the equal distribution of direct support across the European Union during that period. This replaces a firm commitment in earlier drafts that, by December 312028 at the latest, all allocated payment entitlements in the Union should have a uniform value.

\subsubsection{Basic payment}

A single scheme across the EU, the basic payment scheme, will replace the SPS and the SAPS schemes as from 2014. There is no explicit justification for this payment in the draft regulation, but it is clear from the impact assessment that it is intended as basic income support. The scheme will operate on the basis of payment entitlements allocated at national or regional level to all farmers according to their eligible hectares in the first year of application, but there will be a link to beneficiaries of the direct payments system in 2011 in order to avoid speculation. All payment entitlements within a member state or region should have the same value by 1 January 2019. Thus the use of the regional model that was optional in the current period is generalised, effectively bringing all agricultural land into the system. The rules on the management of entitlements and the national reserve largely follow current rules.

For those member states currently applying the historic model of the Single Payment, a "dynamic hybrid" model is proposed to attain a uniform payment by 2019. In 2014 50\% of a farmer's basic payment must be calculated on a uniform basis while the remainder can be distributed according to the historic basis. Over the 2014-2019 period member states must move to a fully uniform payment "through annual progressive modifications ...in accordance with objective and nondiscriminatory criteria". However, taken together with the green payment which will also be distributed on a uniform per hectare basis, there is a rather abrupt shift to a largely uniform payment in the first year, 2014. 
A. Matthews - Post-2013 EU Common Agricultural Policy, Trade and Development: A Review of Legislative Proposals

The actual value of the basic payment per hectare is not fixed in advance but is determined as a residual once the other payments financed from Pillar 1 are accounted for. Assuming that the Commission's proposal in the MFF to hold the budget for direct payments constant in nominal terms is accepted, and assuming that a member state makes use of all of the opportunities for targeted payments in the proposed regulation and sets aside $5 \%$ of its national ceiling for coupled payments, then on average the basic payment would amount to around $55 \%$ of the value of the single payment currently. This proportion will be smaller in those member states that lose funding under the convergence proposal and will be greater in those member states that gain funding under the convergence proposal, given that convergence means that the overall national ceiling will be increased in some countries but decreased in others. Because none of the direct payments are index-linked, their real value will fall gradually over time.

\subsubsection{Green payments}

The green payment is the most innovative element in the proposed direct payments regulation, and follows through on the Commission's commitment to target Pillar 1 measures more closely to the delivery of environmental public goods. The green payment will be paid for "compulsory practices to be followed by farmers addressing both climate and environment policy goals". The practices take the form of simple, generalised, noncontractual and annual actions that go beyond cross-compliance. The threeconditions outlined in the draft regulation are a requirement that cultivation on arable land must consist of at least three different crops simultaneously (not sequentially), that permanent grassland must be maintained at the 2014 level of the individual farm ${ }^{6}$, and that farmers must devote $7 \%$ of their eligible area excluding permanent grassland (thus mainly a requirement on the arable area including permanent crops) to ecological focus including land left fallow, buffer strips and afforested areas. In effect, this is the reintroduction of setaside but for all arable farmers with more than 3 ha of arable area. Organic farming automatically benefits from this additional payment, while farmers in Natura 2000 areas will have to comply with the relevant requirements to the extent that they are consistent with the Natura 2000 legislation.

Contrary to the impression given in the November 2010 Commission Communication that the green payment would be mandatory for member states to offer but voluntary for farmers to accept, the proposed regulation requires that every farmer who wishes to receive a basic payment (apart from those who opt for the small farmer version of the scheme) must also enrol in the green payment scheme and adopt these conditionalities. This means that these environmental conditions become part of a super-cross-compliance conditionality because they must be met if the farmer is to remain eligible even for the basic payment.

A further, voluntary, measure with potential environmental benefits is that member states can use up to $5 \%$ of their national ceilings to top-up the basic payment with an additional, annual, area-based payment to all farmers operating in areas with specific natural constraints. Such payments would be complementary to support given to these farmers under rural development programmes financed from Pillar 2.

\subsubsection{Greater targeting of beneficiaries}

Given that the option of targeting direct payments solely on the delivery of public goods (which was the third, refocus scenario option in the impact assessment) was rejected, the extent to which payments are more targeted in the proposed regulation is limited. Some modest capping of payments is proposed, as well as restricting payments to active farmers. In addition, specific support to new entrants to farming is proposed.

Direct payments (excluding the green payment) to very large farms will be subject to progressive capping on amounts above $€ 150,000$, although account will be taken of 
agricultural employment on large farms in setting the thresholds above which payments will be reduced or capped. Funds released by capping direct payments will remain with that member state. The Commission has regularly proposed the capping of payments since the original MacSharry reforms in 1992 but has made only limited headway (in the Health Check, for example, capping emerged as higher levels of modulation of Pillar 1 payments to Pillar 2 for larger farms). It may stand a greater chance of success with this latest proposal, because of the way in which the thresholds will be increased by the salaries paid to hired workers.

For example, the maximum threshold proposed for payments is $€ 300,000$ which, at the current average EU-27 payment, would be equivalent to a farm of about 1,200 ha (given the expected average level of the basic payment in future, this size threshold would be even greater). If such a farm had ten employees earning, say, $€ 30,000$ annually, then the de facto threshold for payments would be $€ 600,000$ (i.e. increased by $10 x € 30,000$ ). Thus, capping is likely to have more of a symbolic than a real value in targeting payments towards lower-income farms.

This conclusion is confirmed in the direct payments regulation which shows, for each country, the amounts to be modulated as a result of capping (European Commission, 2011f). The overall amount modulated to Pillar 2 at EU-27 level would be 0.4\%.7 Higher percentages would be involved in some member states (Bulgaria 1.3\%, Hungary 0.7\% Romania $0.8 \%$, Slovakia $0.7 \%$, UK $2.5 \%$ ). Funds released by capping direct payments in each member state are reserved for financing projects relating to improving farm competitiveness, including of large farms.

Support will be limited to active farmers. The definition of an active farmer caused much angst, and the definition proposed (to exclude operators whose direct payment receipts are less than $5 \%$ of their total revenue) may well exclude airports, sports clubs and others who are currently eligible for payments. It is proposed not to enforce this test when the total of direct payments to an operator does not exceed $€ 5,000$ per year, in order to avoid accidentally excluding part-time farmers who are seen to play a valuable role in maintaining farming in more marginal farming areas.

It will also be mandatory for member states to set-aside up to $2 \%$ of their annual national ceiling to assist young farmers taking over a farm, which may be complemented by establishment aid under the rural development Pillar.

Whether these changes to the design of the EU direct payments scheme will result in greater targeting of payments to beneficiaries may be doubted. The beneficiaries themselves will change. There will be a redistribution among economic size classes of farms (payments per hectare and income per Annual Work Unit would decrease in the largest farms and increase in the lower size classes) and among various farm types (where drystock and horticultural farms will gain at the expense of dairy and crop farms). However, it is unlikely that there will be much change in the "uneven" distribution of support among farms at EU level (Velazquez, 2008). This is because an EU-wide flat rate payment would link the distribution of payments to the distribution of land among beneficiaries, and the distribution of land is as skewed as the distribution of production (which is the historic reference for payments).

\subsubsection{Small farmer scheme}

Member states must introduce the option of a small farmer payment for which farmers optionally can apply. This will be a simple flat rate payment of between $€ 500$ and $€ 1,000$, the exact value determined by one of two calculation methodologies set out in the regulation. At this level, the scheme will be only of interest to small farmers in the new member states. Apart from those small farmers for which there may be a monetary incentive to enter the scheme, the scheme could attract other farmers with low payments because receipt of the payment, exceptionally, does not require a farmer to enrol in the 
A. Matthews - Post-2013 EU Common Agricultural Policy, Trade and Development: A Review of Legislative Proposals

green payment scheme and to meet the environmental restrictions of that scheme. Small farmers enrolled in this scheme will also be exempt from cross-compliance inspections and sanctions, although with respect to the statutory requirements they must continue to observe these requirements in any event.

\subsubsection{Coupled payments}

The legislative proposal allows voluntary coupling where certain conditions are met. Member states can grant up to $5 \%$ of their national ceiling to sectors or regions where specific types of farming or specific agricultural sectors undergo certain difficulties and are particularly important for economic and/or social reasons. This proportion is increased to $10 \%$ of their national ceiling for the new member states and those old member states whose coupled support exceeded $5 \%$ in at least one of the years in the period 2010-2013. Where a member state coupled more than $10 \%$ of its direct payments in this period, it can apply to the Commission to continue to use more than $10 \%$ of its national ceiling for coupled payments provided it meets a series of conditions set out in the legislative proposal. ${ }^{8}$ Member states decide on the share of direct payments to be coupled when they first opt for this arrangement, but can revisit their decision, within these limits, in 2017.

The use of coupled payments, which in the current regulation would be confined to suckler cows, sheep and goats, rice and cotton after 2013, would be extended to all main agricultural enterprises, including short rotation coppice. On the other hand, member states will lose the possibility to provide support to specific agricultural activities entailing agri-environment benefits under Pillar 1 (the current Article 68(1)(v) of Regulation (EC) No. 73/2009), while support for risk management schemes are also moved to Pillar 2.

\subsubsection{Cross-compliance}

Cross-compliance requirements currently consist of separate lists of statutory management requirements (SMRs) and standards of good agricultural and environmental condition of land. The regulations on cross-compliance are moved from the direct payment regulation to the horizontal regulation. It is proposed to organise these in a single list grouped by area and issue. Some changes are proposed to the details of SMRs, including the addition of the Water Framework and Sustainable Use of Pesticides directives.

\subsubsection{Other issues}

The financial discipline mechanism introduced in the 2003 Fischler reform will be maintained, whereby payments can be reduced to ensure that total payments in the EU as a whole stay within the MFF ceiling, but the mechanism will only apply to payments above the first $€ 5,000$ in any calendar year. The $€ 300$ million margin for triggering financial discipline is no longer operative. The regulation provides for a possible review of the schemes, in particular in the light of economic developments or the budgetary situation, implying that beneficiaries cannot rely on support conditions remaining unchanged.

Member states will have the option, before 1 August 2013, to transfer up to $10 \%$ of their national ceiling to rural development programming for the period of the regulation. Apart from capping, this is the only faint echo of modulation left in the legislative proposal. ${ }^{9}$ Conversely, a specified number of (mainly new) member states can transfer up to $5 \%$ of their 2015-2020 allocation for rural development measures to direct payments. These are member states where the level of direct payments remains below $90 \%$ of the EU average.

\subsection{Market Measures}

The organisation of commodity markets has been at the core of the CAP since its foundation, but the amount of support provided through market intervention measures has gradually been reduced under successive CAP reforms. Despite calls from some quarters for a reversal 
of this process, and for the reintroduction of high support prices underpinned if necessary by supply control measures such as quotas, the legislative proposal maintains the current market orientation.

The main "new issues" addressed in the regulation are volatility and bargaining power in the food chain. Volatility is addressed by generalising the possibility of support in the case of market disturbances due to a loss of consumer confidence, an animal disease outbreak or price volatility (in addition to the enhanced risk management toolkit available in Pillar 2). Efforts to strengthen the bargaining power of producers in the food chain include promoting the use of written contracts and facilitating the formation of producer organisations in sectors other than fruit and vegetables where they have long played a role.

\subsubsection{Elimination of remaining supply restric- tions}

The milk quota system and the vine planting ban are set to expire under existing legislation which is left unchanged in this respect. Sugar quotas are also due to expire by 30 September 2015, and the Commission proposes to maintain this date and not to propose any further extension.

\subsubsection{Harmonisation of the market disturbance clause}

EU agricultural markets have traditionally been supported in the face of price volatility by operating a public intervention system, supplemented by private storage, withdrawals and subsidies for consumption. Public intervention remains for some products, but only at a very low safety net level. The market measures regulation aims to expand and simplify provisions on the basis of experience to date with public intervention, private storage, exceptional/emergency measures and aid to specific sectors.

The general market disturbance clause, which is currently limited to specific sectors, is generalised to include all sectors covered by the common market organisation. To ensure sufficient flexibility to respond to unexpected emergencies, there is a proposal for a new Special Reserve in the MFF regulation for crises in the agriculture sector with an annual ceiling of $€ 500$ million to be mobilised over and above the ceilings of the financial framework. This is complemented by a number of other provisions to assist farmers to cope with market disruption. The animal disease/loss of consumer confidence provision allows aid to be extended to livestock producers facing market disruption due to animal disease or a food safety breakdown. Given the experience with the e.coli outbreak in Germany in summer 2011, this is now extended to plant products as well. Farmers will also be made potential beneficiaries of the Global Adjustment Fund which, for example, could provide assistance to farmers adversely affected by trade agreements. Finally, there is the provision that member states can use some of their Pillar 1 national ceiling to couple payments to products which are adversely affected by continuing disturbances on that market.

\subsubsection{Improved functioning of the food chain}

Discussions in the High Level Expert Group on Milk, which was established to discuss midterm and long-term arrangements for the dairy sector given the expiry of milk quotas, pointed to the need to improve the functioning of the food chain. The Commission regulation implements a number of its recommendations. The product coverage for recognition of producer organisations and their associations as well as inter-branch organisations by member states is extended to all sectors covered by the single $\mathrm{CMO}$ regulation.

Member states are authorised to require written contracts in particular sectors. While generally contract conditions are left up to member states to specify, specific conditions must be included in contracts in the milk sector where a member state decides to make them mandatory with a view to strengthening the bargaining power of milk producers in the food chain. 
A. Matthews - Post-2013 EU Common Agricultural Policy, Trade and Development: A Review of Legislative Proposals

As a further measure to strengthen the bargaining power of milk producers, producer organisations representing dairy farmers will be given the power to negotiate contract terms, including price, for some or all of their members' production with a dairy. To avoid anti-competitive practices, the share of national milk production controlled by a producer group will not be allowed to exceed specific limits (the limits specified in the regulation are $33 \%$ of total national production and $3.5 \%$ of total EU production).

\subsubsection{Measures to support quality production}

Following the Communication from the Commission on agricultural product quality, marketing standards for particular sectors and products are maintained. These relate to such matters such as product definitions, grading into classes, presentation and labelling, packaging and production methods. The proposed regulation introduces a basic general marketing standard for products not covered by specific standards.

\subsection{Rural Development}

The EU's rural development policy co-financed with member states under Pillar 2 is a much more varied set of instruments than found under Pillar 1. Rural development policy in the 2007-2013 period was based on a strategic programming approach based around four axes, where each axis comprised a coherent set of measures supposedly focused on a single objective. Three of these are thematic axes dealing with the improvement of agricultural and forestry competitiveness, sustainable land management, and rural economic diversification and the improvement of the quality of life in rural areas. The fourth methodological axis is dedicated to the LEADER approach to local development through local action groups.
2.3.1 New rural development priorities instead of axes

The Commission's legislative proposal for rural development retains the long-term strategic objectives of contributing to the competitiveness of agriculture and forestry, the sustainable management of natural resources and the balanced territorial development of rural areas. In line with the Europe 2020 strategy, these broad objectives of rural development support for 2014-2020 are given more detailed expression through six EU-wide priorities. These are: fostering knowledge transfer in agriculture and forestry; enhancing competitiveness of all types of agriculture and enhancing farm viability; promoting food chain organisation and risk management in agriculture; preserving and enhancing ecosystems dependent on agriculture and forestry; promoting resource efficiency and the transition to a low carbon economy in agriculture and forestry; and realising the jobs potential and development of rural areas. It is intended that these priorities should be the basis of programming, including the definition of target indicators in relation to each of them.

In the 2007-2013 period, the rural development regulation specified that a minimum amount of each member state's Pillar 2 budget ceiling should be spent on each axis. The Commission now recognises that most measures serve more than one objective or priority. It therefore deems it no longer appropriate to group them into axes. In the next period, programming will take place on the basis of the six priorities which the Commission believes should be sufficient to ensure balanced programmes. However, member states will still be required to maintain 25\% of their Pillar 2 budget for issues related to land management and the fight against climate change.

\subsubsection{Improved coordination with other EU funds}

A continuing source of tension in the programming of rural development funds has 
been that other EU funds (for example, the European Regional Development Fund, the European Social Fund, the Cohesion Fund and the European Maritime and Fisheries Fund) might also be supporting projects in rural areas but there was very little coherence or coordination between them. Each of these funds is administered by a different DirectorateGeneral and is often implemented through different ministries in the member states.

There has long been a strand of opinion that rural development spending should be separated from the CAP and become part of regional spending. Indeed, this was one of the options considered in the refocus scenario in the impact assessment. However, the rural development regulation maintains the traditional division of labour. To overcome the coordination deficit, the regulation provides that rural development spending in Pillar 2 of the CAP should work in a coordinated and complementary manner with Pillar I, as well as with other EU funds. All funds are placed under a Common Strategic Framework (CSF) at EU level which will be transposed into Partnership Contracts at national level. The CSF will replace the current approach of establishing separate sets of strategic guidelines for these funds. An apparent corollary is that monies from these other funds can be used to support the priorities in the rural development regulation.

\subsubsection{New allocation criteria for Pillar 2 funds}

The distribution of rural development funds across member states remains to be decided. The Commission has indicated that this will be based on objective criteria linked to the objectives of a competitive agriculture, sustainable management of natural resources and balanced territorial development of rural areas, but also taking into account past performance. This latter is presumably intended to prevent any sharp redistribution of resources arising from the application of the objective criteria between the member states.

Various allocation options using objective criteria are considered in the impact assessment (European Commission, 2011d). Possible objective economic criteria include agricultural area and labour force as indicators of the size of the agricultural sector and labour productivity as an indicator of the extent to which the sector is lagging behind. Possible objective environmental criteria include agricultural area, Natura 2000 area, natural handicap area, or forest and permanent pasture areas as indicators of the public goods provided. For the territorial balance objective, possible objective indicators include rural population as an indicator of the target group benefiting from the support while the extent to which rural areas are lagging behind is covered by the use of a GDP coefficient for the whole formula.

As is the case with Pillar 1, allocations using objective criteria differ considerably from the current distribution. Various pragmatic solutions to limiting the resulting redistribution are outlined in the impact assessment. Applying these criteria judiciously could even allow the current distribution to be reproduced. It is clear that so-called "objective criteria" are far from objective and in fact are highly political. The Commission regulation proposes to leave the resolution of this issue to a Commission implementing act to be adopted under the examination procedure rather than including a specific formula in the regulation itself which is bound to be controversial.

\subsubsection{Simplification of supported measures}

The list of individual measures has been streamlined and reduced from over 40 to less than 20 (see Table 2 in the Annex for a list of proposed measures). Individual measures have been reviewed, with a number of adjustments introduced to address issues on implementation and uptake raised in the current period. Agri-environment and LEADER remain the only compulsory measures which must be implemented by member states. LEADER will continue in more or less its present form, although with greater coordination with other local action groups funded from other EU funds. The legislative proposal requires that $5 \%$ of the total Pillar 2 contribution shall be reserved 
A. Matthews - Post-2013 EU Common Agricultural Policy, Trade and Development: A Review of Legislative Proposals

for LEADER (this is the same percentage as at present for the old member states but will represent an increase from the minimum $2.5 \%$ for the new member states).

A specific measure for organic farming is created, and a new delimitation for areas facing specific natural constraints is introduced. More support will be provided for co-operative actions within the food chain, within clusters and networks, and for the new operational groups set up under the European Innovation Partnership (see below). Aid to encourage earlier farm retirement has been eliminated.

The measures include an enhanced risk management toolkit, including support to mutual funds and a new income stabilization tool offering new possibilities to deal with the strong volatility in agricultural markets that is expected to continue in the medium term.

Thematic sub-programmes aiming to address specific needs contributing to the Union priorities can be identified in regional programmes, particularly to address the needs of young farmers, small farms, mountain areas and short supply chains. They can also address specific needs relating to the restructuring of agricultural sectors with a significant impact on the development of a specific rural area.

Despite the introduction of a specific priority to promote the transition to a low carbon agriculture and food economy, including fostering carbon sequestration, no new measure to specifically address this priority has been included (although other measures, such as the farm advisory service and aid for investment, can be targeted to climate change measures).

2.3.5 European Innovation Partnership on Agricultural Productivity and Sustainability

This new instrument is aimed at promoting resource efficiency, building bridges between research and practice and generally encouraging innovation. The European Innovation Partnerships (EIP) are a new approach to innovation which were first proposed in the Europe 2020 strategy (European Commission, 2010c) and further elaborated in the Commissions' Communication on an Innovation Union in 2010 (European Commission, 2010d) with a view to speeding up the development and deployment of the technologies needed to meet the various challenges for Europe identified in those documents. The Partnerships themselves focus on improved governance arrangements to help speed up the adoption of research findings and to overcome the fragmentation of research activity in Europe. The intention is that the agricultural Partnership will act through operational groups bringing together farmers, advisors, researchers and businesses who will propose innovative projects and ensure broad dissemination of the results. These groups will be able to draw on a proposed increased budget of $€ 4.5$ billion in funding in the next EU research programme (compared to less than $€ 2$ billion in the current period (House of Lords, 2011) which will be ring-fenced for research into food security, the bio-economy and sustainable agriculture.

\subsubsection{Implementation and monitoring}

The regulation includes rules on the preparation, approval and revision of programmes that largely follow current rules. It opens up the possibility for sub-programmes (e.g. young farmers, small farmers, mountain areas, short supply chains) that benefit from higher aid intensities. Member states are encouraged to provide support with different financial instruments, such as loan funds, guarantee funds and venture capital funds, under common EU rules for these types of instruments. A performance reserve will be established as part of the performance framework, amounting to $5 \%$ of the Pillar 2 contribution to each RD programme plus assigned revenue. It will be allocated in 2019 on the basis of a review by the Commission. 


\section{PRODUCTION AND TRADE EFFECTS OF THE LEGISLATIVE PROPOSALS}

The Commission's 2013 legislative proposals contain a number of measures likely to affect the level of EU domestic production and thus the impact of EU agricultural policy on third countries, including developing countries. The most significant will be the market measures confirming the elimination of milk and sugar quotas. But changes in the design of direct payments, including the overall budget for these payments, redistribution across farmers and member states, the introduction of the greening component, and the extent to which payments can be coupled or not, can also potentially have market effects. From the point of view of third countries, the question is what impact these proposed reforms will have on them.

On balance, it is probable that the proposals will reduce EU production capacity at least in arable crops relative to the status quo. This is because of the requirement to maintain permanent pasture at current levels (which will restrict the ability of EU farmers to plant more arable crops if world prices remain high), the de facto re-introduction of setaside at a rate of $7 \%$ of the arable area and the requirement to diversify crops on a farm basis and to move away from monoculture. In addition, the requirements to move towards greater equality in the allocation of direct payments across member states as well as to a uniform rate in those member states which currently continue to use the historic model of entitlements will reduce support in more productive countries, regions and sectors in favour of more marginal regions. While there is debate about the magnitude of the production effect of direct payments, the academic literature underlines that there can be some effect, so this redistribution will also tend to lower production levels in the more productive farming areas of the EU. ${ }^{10}$

There are some offsetting elements to these production-depressing factors. First, there will still be scope for coupling payments, no longer limited to suckler cows, sheep and goats, and cotton, which would keep production of commodities supported in this way at levels higher than it would otherwise be. Second, quotas on sugar production will be removed after 2015 (but as the arable area cannot be increased, any expansion of sugar beet production would be at the expense of other arable crops). Third, there is a greater emphasis in Pillar 2 on innovation, especially through the European Innovation Partnership and additional resources for agricultural research. However, it is possible that much of this innovation will be focused on adjustment to low-emission and low-carbon agriculture rather than production-enhancing research. Fourth, the greater emphasis on delivering environmental public goods could lead to a longer-term improvement in agricultural productivity due to adoption of more sustainable farming methods (for example, by helping to improve soil quality, by increasing the availability of pollinators, or by increasing resilience to climate change).

On balance, the greater priority given to achieving the delivery of environmental public goods will mean that EU production potential will be lower than it otherwise would be. This conclusion is now examined in more detail for some of the main measures in the Commission package likely to affect EU supply.

\subsection{Impacts from Elimination of Milk and Sugar Quotas}

The decision not to renew the milk quota regime when it expires on 1 April 2015 was previously taken during the 2008 CAP Health Check negotiations, but it is confirmed in the Commission's legislative proposals. At that time, Ministers committed to a "soft landing" approach in which milk quotas are increased by $1 \%$ each year from 2009 to 2013, before the quota system is abolished altogether on 
A. Matthews - Post-2013 EU Common Agricultural Policy, Trade and Development: A Review of Legislative Proposals

1 April 2015. This was to ensure that supply increased in line with increases in EU domestic demand to avoid disruption of the EU market. The concerns of some member states that increased supply would have a negative effect on market prices were met by the inclusion of new possibilities for dairy aid in the Article 68 national envelopes in Pillar 1.

The most recent Commission projections for the EU milk market (published in December 2010) suggest that quota abolition will have a very modest impact on EU-27 milk deliveries after 2015 (European Commission, 2010b). Despite the prospect of buoyant dairy product prices, Commission analysts believe that the steady increase in milk production costs will limit incentives for a strong expansion in milk production. Thus, growth in milk production will remain below the potential growth rate provided by the gradual elimination of the quota regime, leading to a steady decline in quota utilisation at the aggregate EU level. In 2014/2015, the last quota year before abolition, Commission projections indicate that EU milk deliveries will be $-8 \%$ below the quota level $(-6 \%$ in the EU-15 and $-18 \%$ in the EU-12). Figure 2 indicates the Commission's expectation that milk deliveries, even at the end of the projection period, will remain considerably below the (expired) quota level.

Figure 2. Quota utilisation for cow's milk delivered to dairies, quota years ('000t)

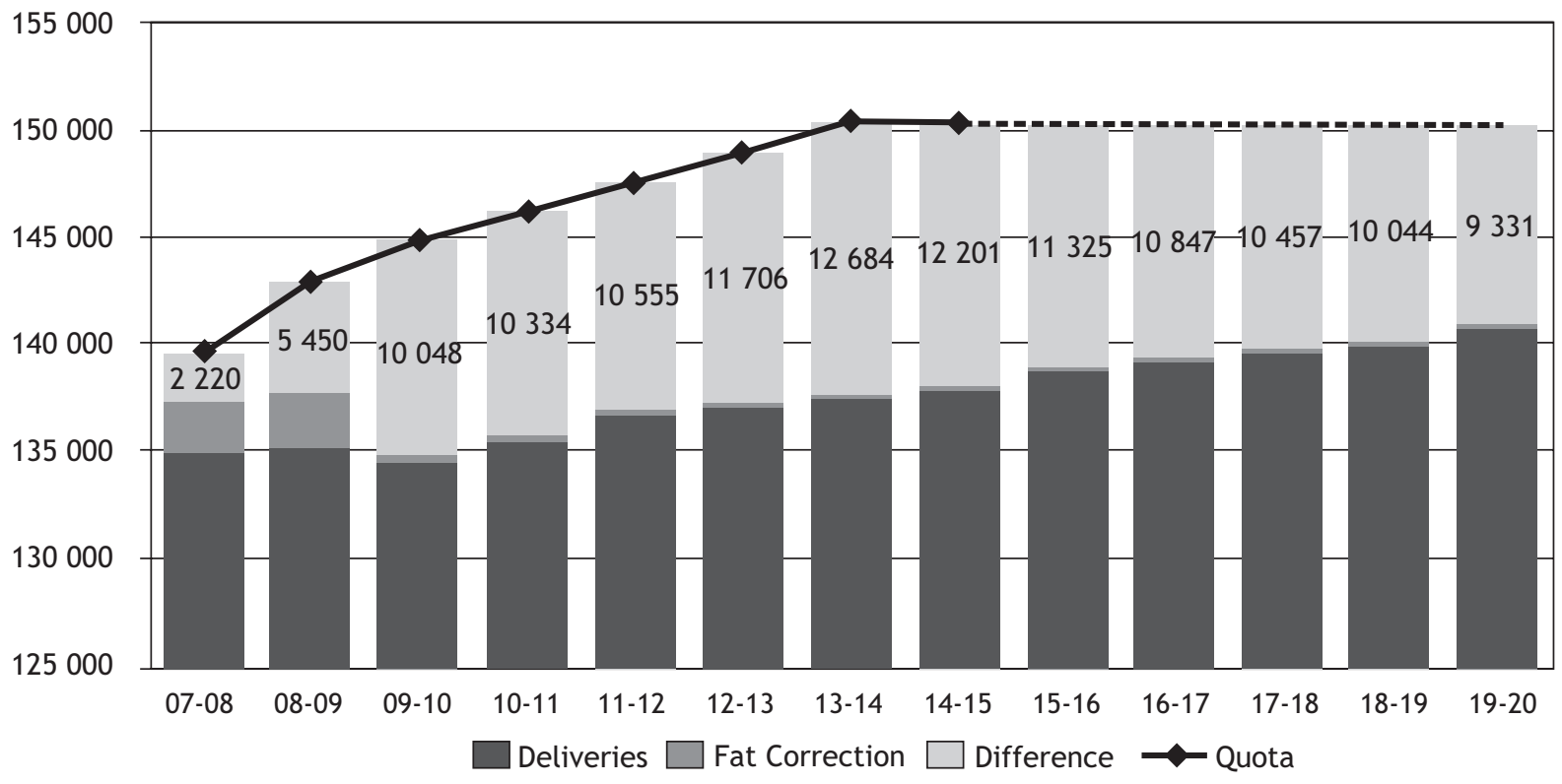

Source: Commission (2010b)

Because the quota regime is administered at farm and member state level, some member states can be constrained from increasing production even if the EU as a whole is under-quota (as well as some dairy farms even in member states which are underquota, depending on what arrangements for the transfer of quota are in place). However, future production increases are expected to be limited to only a few member states (Netherlands, Belgium, Ireland) and to have, overall, a limited impact on milk deliveries at the aggregate EU level.
As far as third countries are concerned, empirical modelling had suggested that EU milk production could be up to $4 \%$ higher without quotas than in the status quo situation with the continuation of milk quotas at the preHealth Check level (FAPRI-Ireland, 2007; IPTS, 2009; Jongeneel, 2011; Réquillart, 2008). Some of this increase has already occurred because of the increase in quotas under the "soft landing" approach since 2009. World demand and prices are also higher than the assumptions made in those studies. Hence, the overall conclusion is that the impact of 
the final elimination of quotas is not expected to have any great significance for world dairy markets.

The most recent reform of the EU sugar quota regime was agreed in 2006 and implemented over a four-year period 2006-2010. This included phased reductions in the EU sugar reference prices by $36 \%$ as well as a voluntary buy-out scheme with the intention to reduce sugar quota volumes by almost $30 \%$. The EU also renounced the Sugar Protocol to the Cotonou Agreement which guaranteed the price at which African, Caribbean and Pacific (ACP) exporters could sell on the EU market but, at the same time, opened duty-free and quota-free access for sugar for ACP exporters. The value of this preferential access to the EU market is influenced by the extent to which EU sugar is diverted to the production of bioethanol and by the generally high world market sugar prices which have prevailed since the start of 2009.

Unlike quota elimination in the milk sector, the Commission's decision not to propose an extension to the sugar quota regime which will thus cease to exist after 2014-15 is a part of the 2013 CAP reform. Also unlike quota elimination in the milk sector, there is limited publicly-available analysis to evaluate the likely impacts of this move.

In its impact assessment of the single CMO regulation the Commission projects a rather benign scenario (European Commission, 2011e). In the baseline, with quotas remaining in place, it projects that EU sugar production (including out-of-quota production) would remain unchanged in 2019/20 compared to 2009/10. EU white sugar prices would be supported at the reference level ( $€ 404 / t)$ and world prices are projected to have fallen back from the high levels experienced in 2009/10 ( $€ 313 / \mathrm{t}$ in $2019 / 20$ compared to $€ 450 / t$ in 2009/10). The no-quota scenario assumes that quotas and support prices are abolished with effect from $2016 / 17$, i.e., one year later than what the Commission now proposes. In its modelling of the impact of quota abolition, the Commission compares the projected situation on the EU and world markets in 2019/20 without quota to the baseline scenario with quota.

Very limited impacts are foreseen. The sugar beet area is projected to be around $2 \%$ higher but yields will be lower due to lower beet producer prices (which would fall below the current reference price). White sugar production is expected to be $1.7 \%$ higher but with consumption also higher because of the lower prices, little impact on the EU's net trade position is expected. Total gross imports are projected to fall by less than $5 \%$ and imports from EBA (least developed) countries and EPA (African, Caribbean and Pacific) countries would fall by less than $7 \%$. World market markets would be virtually unaffected in its analysis.

Nolte et al. (2011) present a more dramatic projection. They compare likely EU production and prices in 2019/20 with quota abolition in 2014/15 under different world price regimes. In their reference scenario, world sugar prices in $2019 / 20$ are very similar to those in the Commission's study ( $€ 362 / t$ in $2019 / 20$ prices, $€ 297 / t$ in $2009 / 10$ prices) and are taken from the 2010 edition of the OECD-FAO Agricultural Outlook (OECD-FAO, 2010)..$^{11}$ EU production is projected to increase to 15.5 million tonnes (excluding out-of-quota sugar) in the non-quota scenario compared to 13.3 million tonnes in the baseline scenario with quotas maintained, or an expansion of $+17 \%$. EU domestic prices would fall by $-26 \%$ to below the EU reference price. If world prices were lower than projected, then the expansion in EU production would also be smaller, while if world prices were higher than projected in the baseline scenario ( $€ 416 / \mathrm{t}$ in 2019/20 prices, $€ 341 / t$ in 2009/10 prices), EU production increases sufficiently to turn the EU into a net exporter again. Without getting too much into the precise figures, this study projects more dramatic impacts for the EU sugar market from the abolition of quotas than the Commission's impact analysis, and thus correspondingly greater implications for developing countries.

Differences in the models used may help to explain some of these contrasting projections. 
A. Matthews - Post-2013 EU Common Agricultural Policy, Trade and Development: A Review of Legislative Proposals

The Commission's model treats the EU as a single unit, while the Nolte et al. model distinguishes supply and demand responses in the individual member states. Nolte et al. effectively treat out-of-quota sugar production (used either for industrial use or bioethanol production) as exogenous and fixed. The reason for the high world sugar market price in their high price scenario might be due to high oil prices and thus the diversion of a substantial proportion of Brazil's sugarcane crop to ethanol production. In this situation, this might also have an effect in the EU market in encouraging some diversion of EU sugar beet production to biofuel use, thus mitigating the adverse impact on preferential imports in this scenario. In general, however, the best returns will come from using beet for white sugar production and the incentive to divert sugar production to fuel rather than food use would be limited given assumed high sugar prices.

\subsection{Greening Impacts}

The implementation of the measures associated with the green payment will increase the costs of farming in the EU either directly or in the form of loss of income in the short-term. The green measures (the requirement to maintain the 2014 level of permanent pasture, the requirement for crop diversification and, particularly, the ecological set-aside) will reduce supply and increase market prices. In the longer-term, there may be a positive feedback from more sustainable agricultural practices in terms of higher yields, but the likely importance of this positive feedback is hard to quantify.

The Commission has made some estimates of the cost of implementing these green measures in its impact assessment (European Commission, 2011g). It concludes that the cost of greening will amount to $€ 33 /$ ha of potentially eligible area (PEA) in 2020. Just half of this figure is the cost of maintaining permanent grassland ( $€ 17 /$ ha PEA). ${ }^{12}$ This suggests that the total cost of greening to EU farmers would amount to approximately $€ 5$ billion, assuming a PEA of around 160 million ha. ${ }^{13}$
As total use of variable inputs in EU-27 agriculture in 2009 was $€ 205$ billion (DG Agriculture and Rural Development, 2011), greening measures would be equivalent to an increase in input costs on average by a little over $2 \%$.

The Commission's impact assessment reports surprisingly high market price impacts for these greening measures. The crop diversification measure pushes prices up for rice and barley, in particular, but down for oilseeds and sugar beet. In general, prices increase more when the ecological set-aside area is expanded than when crops are more diversified because a larger land area is affected. The impact of requiring the maintenance of permanent pasture at 2014 levels does not seem to have been separately assessed.

According to the Commission, EU wheat and sugar beet prices might increase by $3 \%$, barley prices could rise by $12 \%$ and rice prices by $39 \% .{ }^{14}$ Livestock prices would be relatively unaffected except for beef, where prices might go up by $7 \%$. However, an expected rise in feed costs of around $8 \%$ would put margins in livestock enterprises under pressure. The positive impact of the market effects from reduced supply do not compensate farmers for the increased cost of implementing green measures in Pillar 1. Once the costs of the greening measures are factored in, farm income falls by around $-2 \%$ on average. However, the fall would be substantially greater on pig and poultry farms (due to higher feed costs) and on dairy farms, while it would be slightly less on wine and horticultural farms and could even turn out slightly positive on arable farms.

\subsection{Impact of Moving to More Uniform Direct Payments}

What might be the production, consumption and trade effects of the Commission's proposals to redistribute direct payments by moving to a flat(ter) structure of direct payments across the member states, and to redistribute payments within member states by moving from the historic model of farm payments (in the majority of member states 
which operate this system) to a regional flat rate system?

If a direct payment is truly decoupled, then moving payments from one farm to another, or from one country to another, will affect relative incomes but not output. But there is widespread agreement (see footnote 11) that even decoupled direct payments do have an effect on production, even if there is less agreement on how strong this effect is in practice. There are now a number of studies which attempt to quantify the effects of redistribution in the EU (Erjavec et al, 2011; Gocht et al, 2011). The general message from these studies is that the production (and thus trade) effects are likely to be small, but that the distributional effects across and within countries could be significant.

In any move towards a flat-rate payment either between or within member states, grazing livestock (beef and sheep) farms are the main beneficiaries (along with wine and horticultural farms). According to the Commission, moving to a uniform flat rate per hectare of PEA across the EU as a whole would see farm net value added per Agricultural Work Unit increase by $10 \%$ on beef and sheep farms, while falling on milk and arable farms (European Commission, 2011c). This redistribution is due, partly, to the inclusion of "naked land" in the eligible area and partly to the reduction in the disparities under the historic model for the Single Payment Scheme. If account were taken of the greening component in Pillar 1 , which means farmers must incur additional costs to become eligible for the payment, then the income gain to grazing livestock is reduced and the income losses on milk and arable farms but also pig and poultry farms are exacerbated.

Redistribution of direct payments (moving from the historic model for entitlement payments to a regional flat-rate system in the EU-15 member states plus Malta and Slovenia, and moving to greater convergence in the value of payment entitlements across member states) will tend to shift payments from more productive to less productive member states, and from more intensive to less intensive farms within member states. Redistribution of payments on its own would thus be expected to have a negative effect on EU production. Recent studies support this intuition but suggest that the effects will be very marginal, in most cases less than 1-2\% (Erjavec et al, 2011; Gocht et al, 2011). The effects are somewhat larger for cereals than for livestock but still rather small. Overall, therefore, the studies support the view that the EU's direct payments are rather decoupled in practice..$^{15}$

One unknown in these calculations is the likely impact of redesigned direct payments on land prices. The Commission notes that moving to a regional model is likely to increase the rate of capitalisation of support in land prices. This is because the flexibility for activating entitlements with additional eligible land is reduced due to the existence of only a very limited amount of "naked" land and the absence of differences in the entitlement level in the regional model. If this argument is correct, it means that less of the payment will stay with the farmer and more will end up in the hands of the owners of land, particularly with rental arrangements. This would further reduce the production-distorting impact of these payments. ${ }^{16}$

\subsection{Coupling Impacts}

The proposed regulations provide that member states can use up to $5 \%$ of their national ceilings to provide coupled support under specific conditions, and this percentage can be increased with the agreement of the Commission if further conditions are met. Coupled payments have significant impacts on production and therefore trade, but the overall impact of the Commission proposal must be evaluated against the scope for coupled payments under the existing CAP regulations.

In the 2003 Fischler CAP reform, there was significant scope to retain partial coupling. For example, member states could continue to couple $25 \%$ of arable payments and $40 \%$ for durum wheat (Article 66 of Regulation (EC) No. $1782 / 2003), 50 \%$ of payments to sheep and goats 
A. Matthews - Post-2013 EU Common Agricultural Policy, Trade and Development: A Review of Legislative Proposals

(Article 67 ), or $100 \%$ suckler cow premium and $40 \%$ of slaughter premium or $100 \%$ slaughter premium or $75 \%$ of special male premium (Article 68). Some coupled payments for minor crops and processing aids also continued.

The 2008 Health Check integrated the partially coupled payments in the arable crops, olive oil and hops sectors into the Single Payment Scheme from 2010. Processing aids and most other coupled payments, including some specific payments in the beef sector, are integrated into the single payment scheme by 2012 at the latest. With the implementation of the Health Check agreement, suckler cow and sheep and goat premia as well as payments for cotton will be the only formally coupled payments still allowed to remain in 2013. The cotton payments arise from the Protocols in the Treaties of Accession of Greece and Spain which provide that the EU would support the production of cotton in the regions where it is important for the agricultural economy, that the support would permit producers to earn a fair income and would include the grant of an aid to production.

The 2003 reform allowed member states to retain up to $10 \%$ of their previously coupled payment ceilings under Pillar 1 for specific supports to farming and quality production (Article 69 of Regulation (EC) No. 1782/2003). The additional payment had to be granted for specific types of farming which were important for the protection or enhancement of the environment or for improving the quality and marketing of agricultural products. Furthermore, the money had to be returned to the sectors from which it was withheld.

In the 2008 Health Check, Article 69 (now renumbered as Article 68 of Regulation (EC) No. 73/2009) expanded the scope of national envelopes while keeping the overall $10 \%$ share of each member state's direct payments ceiling. Its purpose remains assistance to sectors or regions with particular difficulties but its use became more flexible. Member states can continue to use these payments for environmental measures or improving the quality and marketing of products or animal welfare. However, the money no longer had to be used in the same sector although this option was continued.

But in addition, this national envelope can now be used to help farmers producing milk, beef, goat and sheep meat and rice in disadvantaged regions or to support economically vulnerable types of farming. It can be used to top up entitlements in areas where land abandonment is a threat. It may also be used to support risk management measures such as contributions to crop and animal insurance premia and mutual funds for plant and animal diseases. Countries operating the SAPS scheme became eligible to use national envelopes for the first time.

In order to prevent any potential breach of the EU's WTO commitments on trade-distorting support, as well as to limit potential distortions to competition within the EU, expenditure on potential trade-distorting measures under Article 68 is limited to $3.5 \%$ of national ceilings. This includes support for types of farming important for the protection of the environment, support to address specific disadvantages, and support for mutual funds. Overall, the share of these coupled payments in national ceilings in 2011 is just under 7\% (some minor payments for protein crops, nuts etc. but also cotton are not included). Specific supports under Article 68 account for $2.6 \%$ of direct payments while partial coupled payments account for $4.0 \%$.

Against this background, the question is whether the provisions in the proposed Commission regulation will make it easier to expand coupled payments in the future or whether they will continue to be constrained to a relatively low percentage of overall EU direct payments. The general overall ceiling of $5 \%$ of total direct payments would suggest that the intention is to keep the share of coupled payments in check. ${ }^{17}$ Payments should be used to maintain production but not to increase it. A higher share of payments can be coupled, but only for those member states which already implement these higher shares. Coupled payments can be used for any of the main agricultural commodities and not only suckler cows, sheep and goats, rice and cotton. On balance, the share of coupled 
payments in total EU direct payments will not increase, but on the other hand, the proposed regulation does not further constrain the use of coupled payments in EU agricultural policy.

\subsection{Future WTO Compliance of EU Direct Payments}

The legislative proposal would not seem to call into question any of the EU's commitments under the WTO Agreement on Agriculture (see also Tangermann, 2011). The legislative proposals do not change in any way the current EU regulations regarding market access and border measures. The single CMO regulation maintains the provision for granting refunds on exports to third countries, based on the difference between prices within the Union and on the world market, and falling within the limits set by the commitments under the WTO Agreement on Agriculture. The entry price system for fruit and vegetables, processed fruit and vegetables and grape juice and musts is maintained. Provision is also made for implementing safeguard duties in addition to normal import duties in line with the EU's Schedule of Concessions in the Uruguay Round.

In the absence of a Doha agreement the present domestic support limit will continue to apply to the EU. Because of its high Base Total Aggregate Measure of Support (AMS) and successive CAP reforms, the EU does not have difficulties in staying within its Amber Box commitment. Its Current Total AMS in 2007/08 was just $€ 12.4$ billion, compared to its revised Final Bound Total AMS for EU-27 of $€ 72.2$ billion (WTO, 2011). The single CMO regulation now makes a distinction between reference prices and intervention prices, making clear (as has been EU practice) that it is the intervention prices for public intervention that correspond to the applied administered prices used in the AMS calculation. Further reductions in the EU's Current Total AMS will occur over the next few years as various non-exempt direct aids are abolished (Josling and Swinbank, 2011) and this rhythm will not be affected by these legislative proposals.

Since 2005/06 the EU has reported expenditure on the SPS and SAPS schemes in the WTO Green Box (Josling and Swinbank, 2011). The rules governing Green Box exemption from domestic support reduction commitments are contained in Annex 2 to the WTO Agreement on Agriculture. To qualify for exemption, domestic support must satisfy two criteria. First, it must satisfy the "fundamental requirement", set out in Paragraph 1 of Annex 2 , that a support scheme "must have no, or at most minimal, trade-distorting effects or effects on production". Additionally, it must satisfy one of a number of policy-specific conditions set out in the remaining paragraphs of Annex 2.

The specific conditions governing schemes providing decoupled income support to producers are set out in Paragraph 6 of Annex 2. It states, in particular, that "The amount of such payments in any given year shall not be related to, or based on, the factors of production employed in any year after the base period." Swinbank and Tranter (2005) have argued that this criterion could be contravened by the obligation in the EU direct payments regulation to match SPS payment entitlements to eligible land in order to receive payments. Furthermore, although there is no requirement to continue production in order to receive decoupled payments, the cross-compliance conditions may themselves indirectly require a minimum level of production. In particular, farmers are obliged to maintain all agricultural land in good agricultural and environmental condition. In the 2003 horizontal regulation (Regulation (EC) 1782/2003), the Community standard for the minimum level of maintenance was specified as the maintenance of "minimum livestock stocking rates or/and appropriate regimes". In the Commission's legislative proposal, this reference to minimum stocking rates is deleted, thus weakening any link that might be made between cross-compliance conditions and production. 
A. Matthews - Post-2013 EU Common Agricultural Policy, Trade and Development: A Review of Legislative Proposals

It is not clear if the EU would notify the green payment as decoupled income support or as an environmental payment. It may have difficulty in justifying it as an environmental payment because the amount of the payment is not obviously linked "to the extra costs or loss of income involved in complying with the government programme". ${ }^{18}$ In the Annex to the Commission's November 2010 Communication (European Commission, 2010a), it claims that the compulsory additional aid for specific "greening" public goods would be based on the supplementary costs for carrying out these actions. But there does not appear to be any analysis which suggests that these costs should amount to $30 \%$ of the direct payments ceiling allocated to each member state. In fact, the Commission's own analysis (reported earlier) suggests that total on-farm costs would amount to around $€ 5$ billion annually, whereas $30 \%$ of the direct payments budget of $€ 42$ billion would amount to around $€ 12$ billion annually.

If it is notified as a decoupled income support, a question might be raised over the eligibility requirement that farmers must maintain existing levels of permanent grassland. Both the Panel and the Appellate Body in United States - Subsidies on Upland Cotton found that policies that have the effect of channelling production into certain crops might potentially be in breach of the specific criteria governing decoupled payments. The issue in question in that case was the exclusion of land used for fruit and vegetables from eligibility for payments. It would be for a future panel to decide if the same reasoning could be used with the permanent pasture restriction to question the Green Box status of the green payment if it is notified as decoupled income support.

Also new in the legislative proposal is that there is a new round of entitlement allocation, in which a farmer's entitlements are updated based on the eligible area he holds in 2014, the first year of the new scheme. In theory, the prospect that entitlements could be based on future areas farmed could give farmers an incentive to keep more land in production to benefit from such future allocation, and thus undermine the requirement that the payment scheme have no or minimal trade-distorting effect. The extent to which it was permissible to update base areas was reviewed in United States - Subsidies on Upland Cotton. Under the United States Farm Security and Rural Investment Act of 2002 farmers were permitted for the purposes of the direct payments regime to update the base areas established earlier for the purposes of the production flexibility contracts regime under the Federal Agriculture Improvement and Reform Act of 1996. Cardwell and Rodgers summarise the outcome of this dispute on this point as follows:

"Brazil argued before the Panel that, where
one decoupled income support regime
was replaced by another with the same
structure, design and eligibility criteria,
then they should have the same base
period. The Community also argued that
continued updating of reference periods
in respect of existing decoupled support
created an expectation that production
of certain crops would reap payment
benefits. The Panel did not consider it
necessary to decide the issue; but it did
observe that the direct payments regime
was a "successor" programme to the
production flexibility contracts regime,
albeit with differences. Also, it felt that
there was no evidence, "only speculation",
as to whether producers would expect
to be able to further update their base
areas in the future. The Appellate Body
similarly eschewed detailed consideration
of this issue." (Cardwell and Rodgers, 2006,
p. 824 , footnote references omitted)

They concluded that, until clear guidance is given by the Panel or Appellate Body on the legitimacy of updating the base areas used in support schemes, WTO Members cannot be sure whether or not it is legitimate to do so to take account of more recent production patterns.

The updating issue has been raised in the WTO Doha Round of trade negotiations. The most 
recent version of the Agriculture Chair's draft modalities (from December 2008) contained language that would expressly forbid the updating of entitlements (WTO, 2008). But in the absence of a conclusion to the Doha Round, there has been no agreement on this measure.
There does not appear, therefore, to be any reason why the legislative proposals might threaten the EU's ability to remain compliant with its Uruguay Round commitments but they continue to leave open questions previously raised about the Green Box status of its direct payments. 
A. Matthews - Post-2013 EU Common Agricultural Policy, Trade and Development: A Review of Legislative Proposals

\section{IMPLICATIONS FOR DEVELOPING COUNTRIES}

The Commission's proposals for new regulations for the EU's agricultural policy after 2013 represent a rather limited modification of the current CAP. Champions of more radical change argue that it is a missed opportunity for real reform. On the other hand, it maintains the greater market orientation of CAP reform pursued since 1992, and the Commission has resisted calls from agricultural interest groups to return to a policy of promoting price stability around a high level of guaranteed prices, if necessary through the use of supply controls, often advocated under the guise of promoting food security. It is possible - some would argue, even likely - that the reform proposals will be further diluted as the legislative proposals are negotiated between the European Parliament and the Council. It is certainly hard to see either body pushing for a more radical reform option than what the Commission has proposed.

\subsection{Food security impacts of the Commission proposals}

The potential impacts of the Commission proposals on EU agricultural production will influence its net trade position and thus the level of world prices for different commodities. The discussion in Section 3 highlighted that the principal changes in the proposals, on balance, will reduce EU production capacity, particularly in arable crops with the exception of sugar. The requirement to maintain permanent pasture at 2014 levels on a farm basis will restrict the ability of EU farmers to plant more arable crops if world prices remain high. The de facto re-introduction of arable set-aside at a rate of $7 \%$ and the requirement to diversify crop production on a farm basis and to move away from monoculture will raise farm costs. The proposals to move towards greater equality in the allocation of direct payments across member states as well as to move to a uniform rate in those member states which currently continue to use the historic model of payment entitlements will reduce support in more productive countries, regions and sectors in favour of more marginal regions. While there is debate about the magnitude of the production effect of direct payments, this redistribution will tend to lower production levels in the more productive farming areas of the EU.

This may seem a rather surprising conclusion in the light of the rather misdirected debate on the importance of food security as an objective of this CAP reform. The Commission's November 2010 Communication noted that the public consultation felt that an important strategic aim of the CAP should be "[t]o preserve the food production potential on a sustainable basis throughout the EU, so as to guarantee long-term food security for European citizens and to contribute to growing world food demand, expected by FAO to increase by $70 \%$ by 2050 " (European Commission, 2010a).

However, it is important to interpret this conclusion correctly. It is saying that the legislative proposals, ceteris paribus, will slightly lower future EU production potential. But whether actual EU production in future will be greater or smaller than today will depend on market conditions. In particular, if global supply tensions persist and world market prices remain high, then EU farmers will undoubtedly respond with increased production. Nonetheless, the EU's share of global agricultural production will be (slightly) smaller than if it had not prioritised environmental public goods so highly.

It is a desirable objective that the EU should contribute to meeting global food needs, but it is also important that it does this in an efficient and sustainable manner. Two observations can be made. The first is that, to the extent that the "greening" measures chosen in the legislative proposals to pursue the delivery of environmental public goods are relatively inefficient and costly, then the EU's production potential will be needlessly reduced. Pursuing its environmental objectives with more targeted and efficient policies might not only yield 
greater environmental benefits, but would also reduce the trade-off with potential production. Second, rather than attempting to maintain and increase production through distortionary public supports, the more appropriate way to increase the EU's production potential is through greater innovation leading to higher productivity. This was recognised in the Commission's November 2010 Communication and is reflected in the proposal for a European Innovation Partnership on agricultural sustainability and productivity and the doubling of research funds for agriculture in the next programming period. Because of the novelty of this instrument and the fact that it is untried, it is hard to predict how important it will be in reversing the trend of declining growth rates of agricultural productivity within the EU (House of Lords, 2011).

\subsection{Coupled payments}

Around $6-7 \%$ of the EU's current direct payments remain coupled. The Commission legislative proposals do not, in themselves, suggest that this percentage will be greatly changed in the post-2013 period. The rules for introducing coupled payments are loosened, in terms of the commodities that are covered. However, it is likely that coupled payments will continue to be used mainly in the beef and sheep/goals sectors. The implication is that production of these commodities will be maintained at higher levels than would be the case if coupled payments were eliminated after 2013.

\subsection{Sugar}

The previous discussion showed that there was considerable uncertainty about the implications for the EU sugar market of quota abolition. The two studies reviewed projected a very minimal impact on world sugar prices, but very different scenarios for preferential imports. The Commission's impact assessment suggests that there would be very limited impacts on sugar imports from preferential exporters (European Commission, 2011e). Total preferential imports would amount to 3.5 million tonnes in 2019/20 (compared to 3.7 million tonnes with the continuation of quotas) and imports from EBA (least developed) and EPA (African, Caribbean and Pacific) countries would amount to 2.5 million tonnes (compared to 2.7 million tonnes with the continuation of quotas).

The Nolte et al. (2011) study, on the other hand, projects that preferential imports would fall from an estimated 3.0 million tonnes in the baseline scenario with quotas to 0.9 million tonnes in its reference scenario using OECDFAO (2010) price projections for 2019/2020 without quotas. With lower world market prices and hence lower EU production after quota abolition, preferential imports would still shrink but by a smaller amount, to 1.9 million tonnes. However, with higher world market prices by 2019/20 (though still below the estimated EU market price) preferential imports would be eliminated. The study contains a detailed breakdown by preferential exporter, including least developed countries and ACP countries. In the reference scenario, these two groups are projected to export $385,000 t$ and $337,000 t$, respectively, compared to 542,000 t and 1.7 million tonnes under the quota non-abolition scenario. With high world market prices, exports from both groups of suppliers would be eliminated.

The Commission impact assessment also investigates the impact of a lower world market price ( $€ 250 / t$ compared to $€ 312 / t$ in its reference scenario). It confirms that preferential imports would be significantly greater if world market prices are lower, as in Nolte et al. It projects preferential imports of 4.8 million tonnes, of which 3.6 million tonnes would be sourced from EBA/EPA suppliers. It does not examine a corresponding high-price scenario but the implication is that preferential imports would be smaller than in its reference scenario. One might assume, however, that in a situation of high world market sugar prices the significance of the access of preferential exporters to the EU sugar market would be less important. 
A. Matthews - Post-2013 EU Common Agricultural Policy, Trade and Development: A Review of Legislative Proposals

\subsection{Cotton}

The EU reformed its cotton regime in 2008 but it remains an anomaly in the post-Fischler landscape of decoupled payments. The reform decoupled $65 \%$ of the previous cotton aid, while $35 \%$ continues to be linked to cotton production as a cotton-specific area payment. ${ }^{19}$ In preparing the reform, the challenge was to find an appropriate balance between respect for the legal obligation in the Protocols agreed when the cotton-producing Member States acceded to the EU and the progressive move to decoupled support initiated by the reform of the CAP in 2003. ${ }^{20}$ Full decoupling would make the gross margin from producing cotton negative in all regions, so cotton production would fall dramatically and could cease in Spain. The $65 / 35$ option was thus a compromise in the light of the Protocol commitment. In fact, the area planted to cotton has declined gradually since the reform was introduced, but there are still 300,000 ha of cotton grown in the EU largely due to the coupled area payment.

The 2008 reform confirmed the link to the cultivation of cotton through a crop specific payment per eligible hectare, in accordance with the objective set out in the Greek Protocol that production in the cotton-producing regions would be maintained. The hectare payments are now fixed at $€ 805.60$ per ha for Greece and $€ 1,400$ per ha for Spain, subject to a maximum base area. The maximum base areas eligible for production aid were reduced and are now set at 250,000 ha for Greece and 48,000 ha for Spain. ${ }^{21}$ The total subsidy is fixed at a maximum of $€ 256$ million.

In the Commission proposed regulation the base areas and yields are maintained but the hectare aid amounts are slightly reduced. For Greece, the hectare aid is set at $€ 764.35$ per ha (previously €805.60) and for Spain, the aid is set at $€ 1,292.66$ per ha (previously $€ 1,400$ ). This reduction in the value of support by $6 \%$ will further reduce the incentive for cotton production in the EU, although the remaining support continues to unbalance the playing field for developing country cotton exporters, particularly in West Africa. However, it should be noted that the recent increase in world cotton prices far exceeds the marginal impact which the removal of the remaining EU cotton subsidies would have.

\subsection{Rice}

Five countries account for the bulk of EU rice production: Italy, Greece, Spain, Portugal and France. EU consumption has been growing while EU production has been rather flat (following a sharp fall in production following the rice regime reform in 2003 there has been some recovery since then, but production remains below its previous peak (evel). The EU tends to produce japonica (round or medium-grain) rice while consuming mainly indica (longgrain) rice, so despite only covering around two-thirds of its consumption, it is both an exporter and importer of rice. Most rice is imported under preferential agreements with India, Thailand, Pakistan and the US.

The requirement under "greening" to limit the area devoted to any one crop to $70 \%$ of total arable land would result in a reduction in the area planted to rice by around $8 \%$ (European Commission, 2011g). The requirement to setaside a further $7 \%$ of arable land area as ecological focus area will also reduce the area planted to rice. Commission projections foresee quite a dramatic increase in the EU market price for rice as a result. This should benefit exporters of the higher quality rice varieties (India, Pakistan, US) in particular.

\subsection{Final remarks}

Developing countries are increasingly heterogeneous in the way they are affected by changes in world food prices and, thus, by changes in EU agricultural policy. The effects depend on the commodity composition of their trade, whether they are net importers or exporters of commodities protected by the CAP, and whether they have preferential access to the EU market and thus are able to share in 
some of the benefits of CAP protection. Each country must individually undertake its own analysis to assess how it might be affected. It is hoped that the analysis in this paper provides some relevant guidelines and parameters for such country-specific analyses.

It remains to stress that, with the possible exceptions of sugar and rice, the order of magnitude of the effects to be expected from implementation of the Commission's legislative proposals for CAP reform post-2013 will be minor, particularly in the context of the swings in world market prices experienced since 2008. The paper has emphasised that the greater emphasis on encouraging farmers to adopt environmentally-friendly farming practices, and the redistribution of direct payments towards farms in more marginal and less productive areas, will lower the EU's production potential compared to a status quo scenario. This will affect arable production in particular. Resulting higher feed prices will also reduce EU pig and poultry production and will also constrain any expansion in milk production which might be anticipated after the elimination of milk quotas. The slight reduction in coupled cotton payments will lead to lower EU cotton production.

While the abolition of milk quotas is not expected to have any significant impact on world markets, the proposed elimination of sugar quotas could result in a substantial increase in production, depending on the level of world market prices over the next decade, although there is disagreement on the magnitude of the likely supply response. Increased EU production will result in lower imports from preferential suppliers, particularly least developed countries and ACP exporters. In a situation where world sugar prices remain high, one study even envisages the elimination of these imports although the Commission's impact assessment is less dramatic. Moreover, the continuation of coupled supports which, on the basis of past experience, will be directed mainly to beef and sheep production, together with the effect of redistributing direct payments to more marginal farming areas where beef and sheep production is more important, will keep EU production of these commodities higher than would otherwise be the case.

This CAP reform was not intended to address the trade barriers used to keep some EU market prices higher than world market levels. The EU has reduced the impact of these barriers for a number of developing countries through extending the scope of preferential access under various trade agreements, and a further reduction is being negotiated in the WTO Doha Round. Nonetheless, developing countries will be disappointed that the opportunity was not taken in this reform to set a final date for the ending of export subsidies. A more ambitious CAP reform, in which the targeting of direct payments was pursued more insistently and coupled payments were phased out, would also have a greater impact in removing the remaining distortions caused by the CAP to world markets. 
A. Matthews - Post-2013 EU Common Agricultural Policy, Trade and Development: A Review of Legislative Proposals

\section{ENDNOTES}

1 According to the Commission, all three scenarios respond to the objectives of the reform but are distinguished by the weight they give to particular objectives. The adjustment scenario broadly assumes a continuation of the current CAP but with a significant harmonisation in the level of payments throughout the EU, some further strengthening of rural development measures to target the challenges identified as priorities (resource efficiency and innovation) and some streamlining of market measures. The integration scenario brings about a more balanced CAP (between policy objectives, member states and farmers) through more "green" targeted measures, and is the scenario adopted by the Commission and largely described in this document. The refocus scenario would be a more fundamental reform; it assumes the gradual phasing out of income support under Pillar 1 and the re-focus of support around the environmental and climate policy objectives through the rural development policy strategic framework (Commission 2010a; 2011a).

2 The proposed CAP budget assumes the maintenance of Pillar 1 and Pillar 2 expenditures in nominal terms at 2013 levels (see European Commission, 2011f, Legislative Financial Statement). A more detailed analysis of the MFF proposal, taking account of the shift of some expenditure items from the CAP budget to other MFF headings and the creation of additional spending heads outside the MFF such as for crisis management in agriculture, shows that agricultural spending could increase in nominal terms and could be maintained even in real terms in the next MFF period. See http://capreform.eu/commission-multiannualbudget-plan-protects-the-cap-budget/.

3 For a comprehensive analysis of the role of the CAP in the EU MFFs, see European Parliament, 2011c.

4 Europe 2020 is the EU's growth strategy for the coming decade. It aims at "smart, sustainable and inclusive growth" with greater coordination of European and member state policies in meeting five high-level objectives on employment, innovation, education, social inclusion and climate/energy.

5 Direct payments are the most prominent element of EU budget support for agriculture. However, market price support provided through restrictive trade barriers still accounts for almost $40 \%$ of the EU Producer Support Estimate as calculated by the OECD for the 2006-08 period (Matthews, 2010).

6 In the framework of cross-compliance under the current direct payments regulation, member states are required to ensure that land which was under pasture in 2003 (in the old member states, later years apply to the new member states) is maintained under permanent pasture. The obligation applies at the national or regional level. The proposed regulation would require that the obligation be met at the individual farm level.

7 This figure is based on the difference between the national ceilings shown in Annex II and the net ceilings shown in Annex III, adjusted for total cotton payments of $€ 256$ million.

8 These conditions include:

the necessity to sustain a certain level of specific production due to the lack of alternatives and to reduce the risk of production abandonment and the resulting social and/or environmental problems; 
- $\quad$ the necessity to provide stable supply to the local processing industry, thus avoiding the negative social and economic consequence of any ensuing restructuring;

- the necessity to compensate disadvantages affecting farmers in a particular sector which are the consequence of continuing disturbances on the related market;

where the existence of any other support available under the direct payments regulation, the rural development regulation or any approved state aid scheme is deemed insufficient to meet the needs referred to in the relevant article.

9 Modulation was introduced, initially on a voluntary basis, in the Agenda 2000 reform as an instrument to transfer resources from direct payments to producers in Pillar 1 to rural development programmes in Pillar 2.

10 The impact of decoupled payments on production has been explored in the literature using both theoretical and empirical models. The theoretical literature acknowledges that decoupled farm payments affect farm production through wealth effects leading to higher investment and changes in attitude to risk; through their impact on farm structural change; by reducing the need for off-farm work; through the impact of their capitalisation into land values; through expectations about future programme eligibility and the basis for future payments; and through conditional requirements on the receipt of the payments such as cross compliance requirements. Much of the empirical work has been undertaken in the United States which has had longer experience with the use of decoupled payments, and is not necessarily transferable to the EU context. Good reviews of the current state of this debate can be found in Bhaskar and Beghin, 2009; McVittie et al, 2009; and Rude, 2008.

11 The model used by Nolte et al. is driven by real (2004/05) rather than nominal prices, but in reporting their results they convert all prices into nominal euro values in 2019/20 using an average compounded inflation rate of $1.7 \%$. To facilitate comparisons with the price assumptions used in the Commission study, their nominal prices are deflated by $18 \%(1.7 \%$ compounded over ten years) to derive prices in approximate 2009/10 money terms.

12 The Commission may have over-estimated the cost of maintaining permanent grassland because its methodology seems to assume that all permanent pasture that could be converted into arable cropland would be by 2020 in the status quo scenario. Its model does not have the capacity to estimate the proportion of permanent grassland that would actually be under threat in 2020 , given the configuration of relative profitability (gross margins) between grazing livestock and other enterprises at that time.

13 For the basis of this rough calculation, see http://capreform.eu/what-is-the-likely-cost-ofgreening-pillar-1/.

14 The Commission's impact assessment of the cost of greening compares scenarios with both $5 \%$ and $10 \%$ ecological set-aside, but not the proposed $7 \%$ contained in the regulation. The impact on supply and thus market prices in moving from $5 \%$ top $10 \%$ is not linear, but for simplicity the price changes reported here have been derived by adding 0.4 times the difference between the two scenarios to the results using the $5 \%$ set-aside option. The results are given separately for the EU15 and EU12, and the text reports those for EU15 only.

15 The effects of moving to a uniform flat-rate payment structure have been simulated using two well-known sector models AGMEMOD and CAPRI. In each case the results are, in part, determined by the modellers' assumptions about how direct payments impact on production as well as by the policy scenarios that they assume. The AGMEMOD study assumes a more severe policy scenario (from a farm perspective) in that the CAP budget for direct payments 
A. Matthews - Post-2013 EU Common Agricultural Policy, Trade and Development: A Review of Legislative Proposals

is reduced by almost half and coupled payments are eliminated. Despite these severe assumptions, the production effects are estimated to be very marginal (ranging from $0 \%$ to $-0.8 \%$ of commodity production in 2020) apart from beef where production is estimated to fall by $-3.3 \%$ largely due to the ending of coupled support. The CAPRI study examines the impact of moving to a uniform payment at the NUTS 1 regional level, member state level and for the EU as a whole (with the level of redistribution and potential impacts increasing in moving to an EU flat rate). Its results also show relatively small production and price impacts. In the EU flat rate scenario, which represents the most radical redistribution of direct payments, production generally falls (by $-1.3 \%$ and $-1.9 \%$ for cereals, by $-1.7 \%$ and $-0.8 \%$ for oilseeds, and by $-0.6 \%$ and $-0.2 \%$ for meat in the EU-15 and EU-10 respectively). The small magnitude of the impacts is due in part to the role of entitlements in limiting land use expansion while allowing for some substitution between grassland and arable land. The findings of these studies are further described in http://capreform.eu/production-effectsof-moving-to-flatter-structure-of-direct-payments/.

16 In the AGMEMOD model, coefficients are applied to direct payments to determine their production effects. For example, a coefficient of 1 would imply that farmers perceive direct payments as equivalent to a price increase of equal magnitude, while a coefficient of 0 would imply that they treat them as totally decoupled. The coefficients used in the AGMEMOD model vary across countries and commodities, for example, to reflect differences in the distorting effect of payments under the historic versus the regional model. For historical payments the coefficients vary between 0.3 and 0.6 , and for regional payments between 0.1 and 0.5 . The coefficients for coupled payments lie between 0.5 and 1.0.

17 The Annex to the Commission's November 2010 Communication (European Commission, 2010a) notes that "This would be equivalent to today's coupled support paid through Article 68 and other coupled aid measures."

18 The Commission notes: "It would not be possible to qualify the greening component as an environmental payment since this would require a costs incurred/income foregone calculation" (European Commission, 2011h, footnote 8, p. 17).

19 In fact, the reform of the EU cotton regime which integrated $65 \%$ of the cotton aid into the decoupled payment system and left $35 \%$ as an area payment was decided in 2004 . The new arrangement entered into force on 1st January 2006. However, the Spanish government contested the 2004 decision and particularly the 65/35 breakdown before the European Court of Justice. In September 2006, the Court ruled that the principle of proportionality had been infringed by the Council and that the reform must be annulled, although the ruling did not question the reform as such. The Court also ruled that the new regime should continue to apply until a new regulation was adopted "within a reasonable time". Following an impact assessment, a new regime maintaining the 65/35 breakdown was introduced in 2008.

20 When Greece acceded to the EC, it requested that support should be given for cotton, given its importance in the agricultural economy of some regions. As cotton was not considered an agricultural product (and therefore not listed in Annex I of the EU Treaty), a specific support regime for cotton was written into the Greek Treaty of Accession as Protocol No 4. This was later extended to Spain and Portugal when they joined the EC.

21 Greece (which accounts for $80 \%$ of EU production) and Spain are the only two significant EU producers. Tiny amounts of cotton are also produced and eligible for support in Bulgaria whereas production in Portugal has effectively ceased. 


\section{REFERENCES}

Bhaskar, A. and Beghin, J., 2009. How coupled are decoupled farm payments: a review of the evidence, Journal of Agricultural and Resource Economics 34, 1, 130-153 (working paper version).

Cardwell, M. and Rodgers, C., 2006. Reforming the WTO legal order for agricultural trade: issues for European rural policy in the Doha Round, International and Comparative Law Quarterly 55, 805-836.

Directorate-General for Agriculture and Rural Development, 2011. Agriculture in the European Union: Statistical and Economic Information 2010, Table 3.1.3, http://ec.europa.eu/ agriculture/agrista/2010/table_en/en31.htm, accessed 5 October 2011.

Erjavec, E., Chantreuil, F., Hanrahan, K., Donnellan, T., Salputra, G., Kožar, M. and van Leeuwen, M., 2011. Policy assessment of an EU wide flat area CAP payments system, Economic Modelling 28, 1550-1558.

European Commission, 2010a. The CAP towards 2020: Meeting the food, natural resources and territorial challenges of the future, $\operatorname{COM}(2010) 672 / 5$, Brussels.

European Commission, 2010b. Prospects for agricultural markets and income in the EU 20102020, DG Agriculture and Rural Development, Brussels.

European Commission, 2011a. The reform of the CAP towards 2020: Consultation document for impact assessment, DG Agriculture and Rural Development, Brussels.

European Commission, 2011b. Proposal for a Council Regulation laying down the multiannual financial framework for the years 2014-2020, COM(2011)177, Brussels.

European Commission, 2011c. Common Agricultural Policy towards 2020 Impact Assessment. Annex 3: Direct payments, Commission Staff Working Paper, DG Agriculture and Rural Development, Brussels.

European Commission, 2011d. Common Agricultural Policy towards 2020 Impact Assessment. Annex 4: Rural Development, Commission Staff Working Paper, DG Agriculture and Rural Development, Brussels.

European Commission, 2011e. Common Agricultural Policy towards 2020 Impact Assessment. Annex 5, Market Measures, Commission Staff Working Paper, DG Agriculture and Rural Development, Brussels.

European Commission, 2011f. Proposal for a Regulation of the European Parliament and of the Council establishing rules for direct payment schemes for farmers under the common agricultural policy, COM(2011)625/3, Brussels.

European Commission, 2011g, Greening - Results of partial analysis on impact on farm income using FADN, Annex 2D, Impact assessment, Common Agricultural Policy towards 2020, Staff Working Paper, Brussels.

European Commission, 2011h, Greening the CAP, Annex 2, Impact assessment, Common Agricultural Policy towards 2020, Staff Working Paper, Brussels.

European Parliament, 2010b. The CAP towards 2020: Working Paper on the EC Communication of 18 November 2010, IP/B/AGRI/NT/2010_17, Brussels. 
A. Matthews - Post-2013 EU Common Agricultural Policy, Trade and Development: A Review of Legislative Proposals

European Parliament, 2010c. Supranational decision making procedures, Fact Sheet 1.4.1, Brussels.

European Parliament, 2011a. The CAP towards 2020: meeting the food, natural resources and territorial challenges of the future (2011/2051(INI)), Report of the Committee on Agriculture and Rural Development, rapporteur Albert Deß, A7-0000/2011, Brussels, 27 May.

European Parliament, 2011b. Resolution of 23 June 2011 on the CAP towards 2020: meeting the food, natural resources and territorial challenges of the future, (2011/2051(INI), Brussels.

European Parliament, 2011c. The CAP in the Multiannual Financial Framework 2014/2020, IP/B/ AGRI/NT/2011_12, Brussels.

FAPRI-Ireland Partnership, 2007. CAP Health Check Analysis: Impact of Milk Quota Expansion, Athenry, Teagasc.

Gocht, A., Britz, W. and Adenäuer, M., 2011. Farm level policy scenario analysis, Joint Research Centre Institute for Prospective Technological Studies, Luxembourg, Publications Office of the European Union.

House of Lords, 2011. Innovation in EU agriculture, Report of the European Union Committee, HL Paper 171, London, The Stationery Office.

Institute for Prospective Technological Studies, 2009. Economic impact of the abolition of the milk quota regime: Regional analysis of the milk production in the EU, European Commission, Seville.

Joint Declaration of the European Parliament, Council, Commission, 2007, Joint Declaration on practical arrangements for the codecision procedure, Official Journal of the European Union C145/5, 30 June 2007.

Jongeneel, R., 2011. European Union dairy policy reform: impact and challenges, in OECD, Disaggregated impacts of CAP reforms, OECD, Paris.

Josling, T. and Swinbank, A., 2011. European Union, in Orden, D., Blandford, D and Josling, T. (eds), WTO Disciplines on Agricultural Support, Cambridge, Cambridge University Press.

Matthews, A, 2010. How might the EU's Common Agricultural Policy affect trade and development after 2013? An analysis of the European Commission's November 2010 Communication, ICTSD Programme on Agricultural Trade and Sustainable Development, International Centre for Trade and Sustainable Development, Geneva, Switzerland.

McVittie,A., Moran, D. and Thomson, S., 2009. A Review of Literature on the Value of Public Goods from Agriculture and the Production Impacts of the Single Farm Payment Scheme, Report Prepared for the Scottish Government's Rural and Environment Research and Analysis Directorate (RERAD/004/09), Scottish Agricultural College.

Nolte, S., Buysse, J. and Van Huylenbroeck, G., 2011. Modelling the effects of an abolition of the EU sugar quota on internal prices, production and imports, European Review of Agricultural Economics, doi:10.1093/erae/jbr043.

OECD-FAO, 2010. OECD-FAO Agricultural Outlook 2010-2019, Paris, OECD.

Réquillart, V. (ed)., 2008. Economic analysis of the effects of the expiry of the EU milk quota system, IDEI Report \# 5, Institute for Industrial Economics, Toulouse.

Rude, J., 2008. Production effects of the European Union's Single Farm Payment, Canadian Journal of Agricultural Economics 56, 457-471. 
Swinbank, A. and Tranter, R., 2005. Decoupling EU Farm Support: Does the New Single Payment Scheme Fit within the Green Box? Estey Centre Journal of International Law and Trade Policy 6, 1, 47-61.

Tangermann, S., 2011. Direct payments in the CAP post 2013, IP/B/AGRI/IC/2011_003, Directorate General for Internal Policies, European Parliament, Brussels.

Velazquez, B., 2008. The Single Payment Scheme in the impact assessment of the CAP "Heath Check". Paper prepared for the 109th EAAE Seminar " The CAP after the Fischler Reform: National Implementations, Impact Assessment and the Agenda for Future Reforms". Viterbo, Italy, November 20-21st, 2008.

WTO, 2008. Revised draft modalities for agriculture, TN/AG/W/W/Rev.4, Geneva.

WTO, 2011. Notification by the EU of its domestic support commitments 2007/08, G/AG/N/ EEC/68, Geneva. 
A. Matthews - Post-2013 EU Common Agricultural Policy, Trade and Development: A Review of Legislative Proposals

\section{ANNEX}

Table 2. Measures proposed in the rural development regulation

\begin{tabular}{|c|c|c|}
\hline Article & Measure & Actions supported \\
\hline 28 & $\begin{array}{l}\text { Knowledge transfer and } \\
\text { information actions }\end{array}$ & $\begin{array}{l}\text { Vocational training, skills acquisition, demonstration } \\
\text { activities, farm visits }\end{array}$ \\
\hline 29 & $\begin{array}{l}\text { Advisory services, farm } \\
\text { management and farm relief } \\
\text { services }\end{array}$ & $\begin{array}{l}\text { Support to public or private bodies set up to provide } \\
\text { advice or training. Advice to farmers should be } \\
\text { linked to at least one Union priority, either cross } \\
\text { compliance, compliance with the green payment in } \\
\text { Pillar } 1 \text {, climate mitigation, soil or water protection, } \\
\text { or occupational safety }\end{array}$ \\
\hline 30 & $\begin{array}{l}\text { Quality schemes for } \\
\text { agricultural products and } \\
\text { foodstuffs }\end{array}$ & $\begin{array}{l}\text { Support for new participation by farmers in quality } \\
\text { schemes }\end{array}$ \\
\hline 31 & Investments in physical assets & $\begin{array}{l}\text { Support for investments to improve agricultural } \\
\text { performance and farm viability; to SME investments } \\
\text { in processing and marketing; and for investments } \\
\text { linked to agri-environment commitments or } \\
\text { enhancing the public amenity value of a Natura } 2000 \\
\text { area or other high nature value area }\end{array}$ \\
\hline 32 & $\begin{array}{l}\text { Restoring agricultural } \\
\text { production potential damaged } \\
\text { by national disasters }\end{array}$ & $\begin{array}{l}\text { Support to farmers or groups of farmers for } \\
\text { investments in preventive actions or for the } \\
\text { restoration of agricultural land and production } \\
\text { potential damaged by natural disasters }\end{array}$ \\
\hline 33 & $\begin{array}{l}\text { Farm and business } \\
\text { development }\end{array}$ & $\begin{array}{l}\text { Start up aid for young farmers, for on-farm } \\
\text { diversification and for development of small farms } \\
\text { as well as aid to investment in non-agricultural } \\
\text { activities by micro and small enterprises in rural } \\
\text { areas }\end{array}$ \\
\hline 34 & $\begin{array}{l}\text { Basic services and village } \\
\text { renewal in rural areas }\end{array}$ & $\begin{array}{l}\text { Support for small-scale investments in infrastructure } \\
\text { including renewable energy, broadband, recreation, } \\
\text { tourism. }\end{array}$ \\
\hline $35-40$ & $\begin{array}{l}\text { Investments in forest } \\
\text { area development and } \\
\text { improvements in viability of } \\
\text { forests }\end{array}$ & $\begin{array}{l}\text { Support for afforestation and investments to } \\
\text { improve resilience and environmental value of forest } \\
\text { ecosystems }\end{array}$ \\
\hline 41 & Setting up of producer groups & $\begin{array}{l}\text { Support to facilitate establishment of producer } \\
\text { groups }\end{array}$ \\
\hline 42 & Agri-environment & $\begin{array}{l}\text { Support to farmers undertaking environmental } \\
\text { commitments going beyond the relevant mandatory } \\
\text { standards }\end{array}$ \\
\hline 43 & Organic farming & $\begin{array}{l}\text { Support to farmers who undertake to convert to or } \\
\text { maintain organic farming practices }\end{array}$ \\
\hline 44 & $\begin{array}{l}\text { Natura } 2000 \text { and Water } \\
\text { Framework Directive payments }\end{array}$ & $\begin{array}{l}\text { To compensate farmers for the costs incurred and } \\
\text { income foregone as a result of Natura } 2000 \text { and WFD } \\
\text { restrictions }\end{array}$ \\
\hline
\end{tabular}




\begin{tabular}{|c|c|c|}
\hline Article & Measure & Actions supported \\
\hline $45-46$ & $\begin{array}{l}\text { Payments to areas facing } \\
\text { natural or other specific } \\
\text { constraints }\end{array}$ & $\begin{array}{l}\text { To compensate farmers for the additional costs } \\
\text { and income foregone related to the constraints for } \\
\text { agricultural production in these areas }\end{array}$ \\
\hline 47 & Animal welfare & $\begin{array}{l}\text { To compensate farmers for animal welfare } \\
\text { commitments which go beyond relevant mandatory } \\
\text { standards }\end{array}$ \\
\hline 48 & $\begin{array}{l}\text { Forest-environmental services } \\
\text { and forest conservation }\end{array}$ & $\begin{array}{l}\text { To compensate private and public forest owners for } \\
\text { forest environment commitments which go beyond } \\
\text { relevant mandatory standards }\end{array}$ \\
\hline 49 & Co-operation & $\begin{array}{l}\text { Support to the establishment, running costs and } \\
\text { direct costs of specific projects or specific forms } \\
\text { of co-operation, including between different food } \\
\text { chain actors, clusters and networks and operational } \\
\text { groups of the European Innovation Partnership }\end{array}$ \\
\hline $50-53$ & Risk management & $\begin{array}{l}\text { Support for premiums for crop and animal insurance } \\
\text { caused by adverse climatic events or pests or } \\
\text { diseases; for contributions to mutual funds to pay } \\
\text { financial compensation to farmers who suffer losses } \\
\text { from animal or plant disease or an environmental } \\
\text { incident; and for contributions to an income } \\
\text { stabilisation tool in the form of contributions to } \\
\text { mutual funds providing compensation to farmers } \\
\text { who experience a severe drop in their income. }\end{array}$ \\
\hline $55-61$ & LEADER & $\begin{array}{l}\text { Support for local development strategies by local } \\
\text { action groups }\end{array}$ \\
\hline
\end{tabular}

Source: Author's compilation. 


\section{SELECTED ICTSD ISSUE PAPERS}

\section{Agriculture Trade and Sustainable Development}

Risk Management in Agriculture and the Future of the EU's Common Agricultural Policy. By Stefan Tangermann, Issue Paper No.34, 2011.

Policy Solutions To Agricultural Market Volatility: A Synthesis. By Stefan Tangermann, Issue Paper No.33, 2011.

Composite Index of Market Access for the Export of Rice from the United States. By Eric Wailes. Issue Paper No.32, 2011.

Composite Index of Market Access for the Export of Rice from Thailand. By T. Dechachete. Issue Paper No.31, 2011.

Composite Index of Market Access for the Export of Poultry from Brazil. By H. L. Burnquist, C. C. da Costa, M. J. P. de Souza, L. M. Fassarella. Issue Paper No.30, 2011.

How Might the EU's Common Agricultural Policy Affect Trade and Development After 2013? By A. Matthews. Issue Paper No. $29,2010$.

Food Security, Price Volatility and Trade: Some Reflections for Developing Countries. By Eugenio Díaz-Bonilla and Juan Francisco Ron. Issue Paper No. $28,2010$. Composite Index of Market Access for the Export of Rice from Uruguay. By Carlos Perez Del Castillo and Daniela Alfaro. Issue Paper No. $27,2010$.

How Would A Trade Deal On Cotton Affect Exporting And Importing Countries? By Mario Jales. Issue Paper No.26, 2010.

Simulations on the Special Safeguard Mechanism: A Look at the December Draft Agriculture Modalities. By Raul Montemayor. Issue Paper No.25, 2010.

Competitiveness and Sustainable Development

The Role of International Trade, Technology and Structural Change in Shifting Labour Demands in South Africa. By H. Bhorat, C. van der Westhuizen and S.Goga. Issue Paper No. 17, 2010.

Trade Integration and Labour Market Trends in India: an Unresolved Unemployment Problem. By C.P. Chandrasekhar. Issue Paper No. 16, 2010.

The Impact of Trade Liberalization and the Global Economic Crisis on the Productive Sectors, Employment and Incomes in Mexico. By A. Puyana. Issue Paper No. 15, 2010.

Globalization in Chile: A Positive Sum of Winners and Losers. By V. E. Tokman. Issue Paper No. 14, 2010.

Practical Aspects of Border Carbon Adjustment Measures - Using a Trade Facilitation Perspective to Assess Trade Costs. By Sofia Persson. Issue Paper No.13, 2010.

Trade, Economic Vulnerability, Resilience and the Implications of Climate Change in Small Island and Littoral Developing Economies. By Robert Read. Issue Paper No.12, 2010.

The Potential Role of Non Traditional Donors 'Aid in Africa. By Peter Kragelund. Issue Paper No.11, 2010.

Aid for Trade and Climate Change Financing Mechanisms: Best Practices and Lessons Learned for LDCs and SVEs in Africa. By Vinaye Dey Ancharaz. Issue Paper No.10, 2010.

Resilience Amidst Rising Tides: An Issue Paper on Trade, Climate Change and Competitiveness in the Tourism Sector in the Caribbean. By Keron Niles. Issue Paper No.9, 2010.

Dispute Settlement and Legal Aspects of International Trade

Conflicting Rules and Clashing Courts. The Case of Multilateral Environmental Agreements, Free Trade Agreements and the WTO. By Pieter Jan Kuijper. Issue Paper No.10, 2010.

Burden of Proof in WTO Dispute Settlement: Contemplating Preponderance of the Evidence. By James Headen Pfitzer and Sheila Sabune. Issue Paper No.9, 2009. Suspension of Concessions in the Services Sector: Legal, Technical and Economic Problems. By Arthur E. Appleton. Issue Paper No.7, 2009.

Trading Profiles and Developing Country Participation in the WTO Dispute Settlement System. By Henrik Horn, Joseph Francois and Niklas Kaunitz. Issue Paper No.6, 2009.

Fisheries, International Trade and Sustainable Development

The Importance of Sanitary and Phytosanitary Measures to Fisheries Negotiations in Economic Partnership Agreements. By Martin Doherty. Issue Paper No.7, 2008 .

Fisheries, Aspects of ACP-EU Interim Economic Partnership Agreements: Trade and Sustainable Development Implications. By Liam Campling. Issue Paper No.6, 2008.

Fisheries, International Trade and Sustainable Development. By ICTSD. Policy Discussion Paper, 2006.

Intellectual Property Rights and Sustainable Development

Sustainable Development In International Intellectual Property Law - New Approaches From EU Economic Partnership Agreements? By Henning Grosse Intellectual Property Rights and International Technology Transfer to Address Climate Change: Risks, Opportunities and Policy Options. By K. E.

Maskus and R. L. Okediji. Issue Paper No.32, 2010

Intellectual Property Training and Education: A Development Perspective. By Jeremy de Beer and Chidi Oguamanam. Issue Paper No.31, 2010.

An International Legal Framework for the Sharing of Pathogens: Issues and Challenges. By Frederick M. Abbott. Issue Paper No.30, 2010.

Sustainable Development In International Intellectual Property Law - New Approaches From EU Economic Partnership Agreements? By Henning Grosse Ruse - Khan. Issue Paper No.29, 2010.

Trade in Services and Sustainable Development

Facilitating Temporary Labour Mobility in African Least-Developed Countries: Addressing Mode 4 Supply-Side Constraints. By Sabrina Varma. Issue Paper No.10, 2009.

Advancing Services Export Interests of Least-Developed Countries: Towards GATS Commitments on the Temporary Movement of natural Persons for the Supply of Low-Skilled and Semi-Skilled Services. By Daniel Crosby, Issue Paper No.9, 2009.

Maritime Transport and Related Logistics Services in Egypt. By Ahmed F. Ghoneim, and Omneia A. Helmy. Issue Paper No.8, 2007.

Environmental Goods and Services Programme

Harmonising Energy Efficiency Requirements - Building Foundations for Co-operative Action. By Rod Janssen. Issue Paper No.14, 2010

Climate-related single-use environmental goods. By Rene Vossenaar. Issue Paper No.13, 2010.

Technology Mapping of the Renewable Energy, Buildings, and transport Sectors: Policy Drivers and International Trade Aspects: An ICTSD Synthesis Paper. By Renee Vossenaar and Veena Jha. Issue Paper No.12, 2010.

Trade and Sustainable Energy

International Transport, Climate Change and Trade: What are the Options for Regulating Emissions from Aviation and Shipping and what will be their Impact on Trade? By Joachim Monkelbaan. Background Paper, 2010.

Climate Change and Trade on the Road to Copenhagen. Policy Discussion Paper, 2009.

Trade, Climate Change and Global Competitiveness: Opportunities and Challenge for Sustainable Development in China and Beyond. By ICTSD. Selected Issue Briefs No.3, 2008.

Intellectual Property and Access to Clean Energy Technologies in Developing Countries: An Analysis of Solar Photovoltaic, Biofuel and Wind Technologies. By John H. Barton. Issue Paper No.2, 2007.

Regionalism and EPAs

Questions Juridiques et Systémiques Dans les Accords de Partenariat économique : Quelle Voie Suivre à Présent ? By Cosmas Milton Obote Ochieng. Issue Paper No. 8, 2010.

Rules of Origin in EU-ACP Economic Partnership Agreements. By Eckart Naumann. Issue Paper No.7, 2010

SPS and TBT in the EPAs between the EU and the ACP Countries. By Denise Prévost. Issue Paper No.6, 2010.

Los acuerdos comerciales y su relación con las normas laborales: Estado actual del arte. By Pablo Lazo Grandi. Issue Paper No.5, 2010.

Revisiting Regional Trade Agreements and their Impact on Services and Trade. By Mario Marconini. Issue Paper No.4, 2010.

Trade Agreements and their Relation to Labour Standards: The Current Situation. By Pablo Lazo Grandi. Issue Paper No.3, 2009.

Global Economic Policy and Institutions

The Microcosm of Climate Change Negotiations: What Can the World Learn from the European Union? By Håkan Nordström, Issue Paper No.1, 2009. 
ICTSD's Programme on Agricultural Trade and Sustainable Development aims to promote food security, equity and environmental sustainability in agricultural trade. Publications include:

- Improving the International Governance of Food Security and Trade. By Manzoor Ahmad. Issue Paper No. 38, 2011.

- $\quad$ Food Reserves in Developing Countries: Trade Policy Options for Improved Food Security. By C. L. Gilbert, Issue Paper No. 37, 2011.

- $\quad$ Global Food Stamps: An Idea Worth Considering? By Tim Josling, Issue Paper No. 36, 2011.

- $\quad$ Risk Management in Agriculture and the Future of the EU's Common Agricultural Policy. By Stefan Tangermann, Issue Paper No. 34, 2011.

- Policy Solutions To Agricultural Market Volatility: A Synthesis. By Stefan Tangermann, Issue Paper No. 33, 2011.

- Composite Index of Market Access for the Export of Rice from the United States. By Eric Wailes. Issue Paper No. 32, 2011.

- Composite Index of Market Access for the Export of Rice from Thailand. By T. Dechachete. Issue Paper No. 31, 2011.

- Composite Index of Market Access for the Export of Poultry from Brazil. By H. L. Burnquist, C. C. da Costa, M. J. P. de Souza, L. M. Fassarella. Issue Paper No. 30, 2011.

- How Might the EU's Common Agricultural Policy Affect Trade and Development After 2013? An Analysis of the European Commission's November 2010 Communication. By Alan Matthews. Issue Paper No. 29, 2010.

- Food Security, Price Volatility and Trade: Some Reflections for Developing Countries. By Eugenio Díaz-Bonilla and Juan Francisco Ron. Issue Paper No. 28, 2010.

- Composite Index of Market Access for the Export of Rice from Uruguay. By Carlos Perez Del Castillo and Daniela Alfaro. Issue Paper No. 27, 2010.

- How Would A Trade Deal On Cotton Affect Exporting And Importing Countries? By Mario Jales. Issue Paper No. 26, 2010.

- Simulations on the Special Safeguard Mechanism: A Look at the December 2008 Draft Agriculture Modalities. By Raul Montemayor. Issue Paper No. 25, 2010.

- How Would a Trade Deal on Sugar Affect Exporting and Importing Countries? By Amani Elobeid. Issue Paper No. 24, 2009.

- $\quad$ Constructing a Composite Index of Market Acess. By Tim Josling. Issue Paper No. 23, 2009.

- Comparing safeguard measures in regional and bilateral agreements. By Paul Kruger, Willemien Denner and JB Cronje. Issue Paper No. 22, 2009.

- How would a WTO agreement on bananas affect exporting and importing countries? By Giovanni Anania. Issue Paper No. 21, 2009.

- Biofuels Subsidies and the Law of the World Trade Organisation. By Toni Harmer. Issue Paper No. 20, 2009.

- Biofuels Certification and the Law of the World Trade Organisation. By Marsha A. Echols. Issue Paper No. 19, 2009.

For further information, visit www.ictsd.org

\section{ABOUT ICTSD}

Founded in 1996, the International Centre for Trade and Sustainable Development (ICTSD) is an independent non-profit and non-governmental organization based in Geneva. By empowering stakeholders in trade policy through information, networking, dialogue, well-targeted research and capacity building, the centre aims to influence the international trade system such that it advances the goal of sustainable development. 